\title{
As Melastomataceae do município de Poços de Caldas, Minas Gerais, Brasil
}

\author{
Luiza Sumiko Kinoshita $^{1,2}$, Angela Borges Martins ${ }^{1}$ e Karina Fidanza Rodrigues Bernardo ${ }^{1}$
}

Recebido: 26.10.2006; aceito: 18.09.2007

\begin{abstract}
The Melastomataceae of the Poços de Caldas region, state of Minas Gerais, Brazil). This paper presents a survey of Melastomataceae collected in the Poços de Caldas region during the research project signed between the Universidade Estadual de Campinas (FUNCAMP), and the ALCOA Alumínios. Several families were collected during this project, among them standing out the Melastomataceae, which comprises a high number of species in the local flora, with 58 species in 12 genera and three tribes. Melastomeae and Miconieae showed the higher number of species. In order to contribute to the final list of the taxa we also included specimens previously collected. We provide descriptions, illustrations, geographical distribution and a key to the genera and species studied.
\end{abstract}

Key words: floristic, Melastomeae, Miconieae, Microlicieae

RESUMO - (As Melastomataceae do município de Poços de Caldas, Minas Gerais, Brasil). Este trabalho trata das espécies de Melastomataceae coletadas na região de Poços de Caldas durante o projeto de pesquisa firmado entre a Universidade Estadual de Campinas (FUNCAMP), através dos docentes do Departamento de Botânica, e a ALCOA Alumínios. Diversas famílias foram estudadas durante este projeto e, dentre estas, destacam-se as Melastomataceae, que apresentam um elevado número de espécies na flora local. Foram registradas 58 espécies distribuídas em 12 gêneros e três tribos. Melastomeae e Miconieae foram as que apresentaram o maior número de espécies. Para complementar a listagem final dos táxons foram também consultados espécimes anteriormente coletados na região. São apresentadas chaves analíticas, descrições, ilustrações e atualização da distribuição geográfica das espécies estudadas.

Palavras-chave: florística, Melastomeae, Miconieae, Microlicieae

\section{Introdução}

A região de Poços de Caldas, Minas Gerais, um planalto de cerca de $1.500 \mathrm{~m}$ de altitude, tem sido muito estudada geologicamente, devido principalmente às jazidas minerais (Christofoletti 1972). Com as constantes explorações destas jazidas, particularmente no município de Poços de Caldas, ficaram comprometidos a proteção dos rios da região, o controle da erosão das encostas, a manutenção das condições climáticas e a paisagem propriamente dita. Além disso, sendo o município turístico, torna-se necessário manter as composições paisagísticas de suas cercanias, preservando-se a cobertura vegetal.

Quanto à recuperação das áreas mineradas, até agora muito pouco tem sido feito. A ALCOA Alumínio S.A., que explorou bauxita no município, firmou convênio com a Fundação de Desenvolvimento da Universidade Estadual de Campinas (FUNCAMP), para tentar uma recomposição da paisagem natural da região. Deste estudo, realizado durante os anos de 1980 a 1984, resultaram coleções botânicas significativas e, em termos florísticos, algumas famílias têm sido objeto de estudos devido ao grande número de espécies que apresentam nesta região, como por exemplo: Asteraceae (Rodrigues 2001), Gramíneas (Pereira 1986) e Apocynaceae (Vasconcellos \& Kinoshita 1993).

A família Melastomataceae compreende cerca de 166 gêneros e 4.500 espécies distribuídas pelas regiões tropicais e subtropicais do globo (Renner 1993). Aproximadamente dois terços das espécies de Melastomataceae encontram-se na América do Sul (Morley \& Dick 2003), onde são amplamente

1. Universidade Estadual de Campinas, Instituto de Biologia, Departamento de Botânica, Caixa Postal 6109, 13081-970 Campinas, SP, Brasil

2. Autora para correspondência: luizakin@unicamp.br 
distribuídas. Nesta região, o maior número de espécies ocorre no Brasil, com várias delas consideradas elementos típicos em diversas formações vegetais (Souza 1998).

Em Poços de Caldas as Melastomataceae são bastante frequientes, sendo encontradas principalmente em áreas de mata estacional semidecidual, campo sujo de altitude, áreas brejosas e também em topo de serras com altitudes de 1.800-1.900 m. Este estudo constitui uma contribuição ao conhecimento da flora do município, fornecendo dados sobre a distribuição geográfica e habitat das espécies da família na localidade, bem como descrições, ilustrações e chaves analíticas para identificação dessas espécies e dos gêneros a que pertencem.

\section{Material e métodos}

O município de Poços de Caldas está situado no sudoeste do Estado de Minas Gerais, a 21 ${ }^{\circ} 51^{\prime} 20^{\prime \prime} \mathrm{S}$ e $46^{\circ} 33^{\prime} 55^{\prime}$ "W e ocupa uma área de $800 \mathrm{~km}^{2}$, a 1.200-1.300 m acima do nível do mar. O clima é do tipo Mesotérmico Brando, com temperatura média de $20^{\circ} \mathrm{C}$ e precipitações que não excedem $320 \mathrm{~mm}$ (Poços de Caldas, INDI, CDI 1974). A região, denominada Planalto de Poços de Caldas, localiza-se na borda ocidental da Serra da Mantiqueira, estendendo-se pelos extremos orientais da Bacia Sedimentar do Rio Paraná. O município apresenta três tipos básicos de vegetação: campos (constituído por gramíneas e arbustos baixos), cerrados e floresta tropical (pouco densa). Os solos têm características geológicas diversas, podendo ser formados por extensa intrusão de rochas alcalinas (Pereira 1986).

Para o desenvolvimento deste trabalho foram utilizados espécimes provenientes de coletas regulares, efetuadas pelos docentes do Departamento de Botânica da UNICAMP, no município de Poços de Caldas no período de 1980 a 1984, totalizando 22 viagens a campo. Para complementar a listagem final das Melastomataceae do município de Poços de Caldas, além dos materiais coletados pelos docentes da UNICAMP, considerou-se também coletas efetuadas por outros botânicos, depositadas em diversos herbários como UEC, HB, IAC, R, RB, S e SP. Dentre estes coletores destaca-se o botânico sueco Regnell que forneceu a maior contribuição para o estudo da flora da região caldense.

A identificação das espécies foi feita utilizando-se chaves analíticas dos gêneros e espécies de Melastomataceae contidas em trabalhos recentes
(Goldenberg 2004, Martins et al. 1996, Baumgratz 1984, 1980, Guimarães \& Martins 1997, Romero \& Martins 2002), como também as obras de Cogniaux (1883-1885, 1886-1888). As descrições das espécies e as chaves analíticas foram elaboradas com base nos espécimes coletados e herborizados, em dados existentes na literatura assim como em informações sobre habitat presentes nas etiquetas dos materiais depositados nos herbários consultados.

As ilustrações foram confeccionadas com base nos materiais coletados em Poços de Caldas e, quando necessário, materiais de outras localidades foram utilizados para complementar as ilustrações dos detalhes morfológicos de algumas espécies. Estes materiais constam no material adicional examinado.

Os gêneros, assim como as espécies, são apresentados em ordem alfabética dentro de cada tribo que também estão nessa mesma ordem.

\section{Resultados e Discussão}

\section{Melastomataceae Juss.}

Árvores, arvoretas, arbustos, ervas, raramente epífitas ou escandentes. Folhas simples, decussadas, raro verticiladas ou em pseudo-fascículos, glabras ou diversamente pilosas, nervuras acródromas basais ou supra-basais, menos freqüentemente subparalelas. Inflorescências ou flores solitárias, axilares e/ou terminais. Flores diclamídeas, dialipétalas, bissexuais, períginas, hipóginas ou epíginas, (3-)4-5(-8)-meras. Cálice com lacínias simples ou duplicadas, persistentes ou decíduas. Pétalas, brancas, lilases, magenta, róseas, roxas, purpúreas, amarelas, lavanda ou vermelhoalaranjadas. Estames em número duplo, maior ou igual ao das pétalas, às vezes estames férteis alternados com estaminódios, isomorfos, subisomorfos ou dimorfos; conectivo prolongado ou não abaixo das tecas, freqüentemente provido de apêndices ventrais ou dorsais; anteras obovais a subuladas, (2-)4 esporangiadas, raro polisporangiadas, 1-2 ou 4 poradas, ápice curto ou longamente rostrado, arredondado ou truncado. Ovário (1-)2-6(-15) locular, súpero a ínfero, ápice glabro ou piloso, geralmente com muitos óvulos por lóculo; placentação axilar; estilete único; estigma punctiforme a truncado. Cápsula ou baga, sementes numerosas, raramente 1 , podendo apresentar diversas formas.

No Brasil as Melastomataceae estão representadas por cerca de 69 gêneros e aproximadamente 1.500 espécies (Renner 1989) que ocorrem desde o 
Amazonas até o Rio Grande do Sul, sendo comum a ocorrência de táxons endêmicos em determinadas regiões (Martins 1984).

No município de Poços de Caldas foram encontradas três tribos: Melastomeae com seis gêneros: Acisanthera P. Browne (1 sp.), Comolia DC. (1 sp.), Microlepis Miq. (1 sp.), Pterolepis (DC.) Miq. (1 sp.), Siphanthera Pohl. (1 sp.) e Tibouchina Aubl. (14 spp.); Miconieae com dois gêneros: Leandra
Raddi (16 spp.) e Miconia Ruiz et Pav. (17 spp.); Microlicieae com três gêneros: Microlicia D. Don (2 spp.), Trembleya DC. (2 spp.) e Rhynchanthera DC. (1 sp.). O gênero Cambessedesia, recentemente excluído de Microlicieae (Fritsch et al. 2004), ainda permanece sem posição definida na família Melastomataceae. Este gênero está representado no município de Poços de Caldas por apenas uma subespécie.

Chave para identificação dos gêneros de Melastomataceae de Poços de Caldas

1. Estames isomorfos

2. Ápice das pétalas agudo ou subulado

11. Leandra

2. Ápice das pétalas arredondado, retuso ou obtuso, nunca agudo

12. Miconia

1. Estames subisomorfos ou dimorfos

3. Flores com pétalas inteiramente amarelas

1. Cambessedesia

3. Flores com pétalas brancas, róseas, purpúreas ou roxas

4. Ápice das anteras rostrado

5. Folhas com glândulas sésseis; flores solitárias

2. Microlicia

5. Folhas sem glândulas sésseis; flores dispostas em inflorescências

6. Estames 10, férteis

4. Trembleya

6. Estames férteis, 5 ou 4, com estaminódios geralmente presentes

7. Flores 5-meras, dispostas em inflorescências bíparas

7. Flores 4-meras, dispostas em glomérulos

3. Rhynchanthera 9. Siphanthera

4. Ápice da antera não rostrado

8. Plantas com indumento estrelado-tomentoso

7. Microlepis

8. Plantas com outro tipo de indumento

9. Lacínias do cálice alternadas com emergências ramificadas

8. Pterolepis

9. Lacínias do cálice não alternadas com emergências ramificadas

10. Ovário piloso, pelo menos no ápice.

10. Tibouchina

10. Ovário totalmente glabro

11. Flores 5-meras; apêndice do conectivo bífido

5. Acisanthera

11. Flores 4-meras; apêndice do conectivo bituberculado

6. Comolia

\section{Tribo Microlicieae}

1. Cambessedesia DC. in DC., Prodr. 3: 110. 1828.

Cambessedesia compõe-se de 22 espécies com distribuição restrita ao território brasileiro, onde podem ser encontradas de Pernambuco e Piauí ao norte do Paraná. Entretanto, a maioria das espécies ocorre no alto de serras da Bahia, Goiás e Minas Gerais, onde muitas delas são endêmicas. Nestes locais ocupam especialmente áreas de campo rupestre e campos de altitude (Martins 1984, 1993). No município de Poços de Caldas foi encontrada apenas Cambessedesia espora subsp. ilicifolia.
1.1. Cambessedesia espora subsp. ilicifolia (DC.) A.B. Martins, Acta Bot. Brasil. 9(1): 148. 1995. Cambessedesia espora var. ilicifolia DC. in DC., Prodr. 3: 111. 1828.

Figura 1E

Subarbustos $0,6 \mathrm{~m}$ alt. Caule e ramos com tricomas curtos e densos. Folhas em pseudofascículos, subsésseis; lâmina 3-5,5 × 1-3,5 mm, oval, base cordada, ápice agudo-apiculado, esparsamente piloso-glandulosa. Inflorescências espiciformes, terminais e/ou axilares. Flores 5-meras. Hipanto 4,5 $\times$ 3,3 mm, cilíndrico, com tricomas glandulares esparsos. Lacínias do cálice 1,8-2,3 × 1-1,2 mm. Pétalas 4,5 × 
2,5 mm, amarelas, oblongo-lanceoladas, acuminadas. Estames 10; conectivo espessado e não prolongado; anteras levemente falciformes. Ovário súpero, tricomas glandulares longos e esparsos no ápice, 3-locular. Cápsula 3,5-4 mm compr. Sementes piramidais, tuberculadas.

Material selecionado: BRASIL. Minas Gerais: Poços de Caldas, 13-I-1981, L.S. Kinoshita et al. 742 (UEC).

Cambessedesia espora subsp. ilicifolia ocorre nos Estados de Minas Gerais, Goiás, Paraná e São Paulo (Martins 1984). Esta subespécie caracterizase por apresentar ramos cilíndricos, revestidos por tricomas curtos e densos, distinguindo-se prontamente da subespécie espora, que apresenta ramos quadrangulares e totalmente glabros. Em Poços de Caldas ocorre em campos graminosos.

2. Microlicia D. Don., Mem. Wern. Soc. 4: 301. 1823.

Arbustos eretos, cespitosos ou não; glabros, pilosos ou glanduloso-pilosos. Folhas sésseis ou subsésseis; lâminas com reticulação não evidente na face abaxial, glabras, pilosas ou com glândulas sésseis. Flores 5-meras; solitárias, terminais e/ou axilares. Hipanto subgloboso, urceolado ou campanulado; glabro ou piloso. Pétalas róseas, lilases, magenta, purpúreas, brancas, amarelas, obovais, levemente acuminadas ou apiculadas. Estames 10; conectivo prolongado abaixo das tecas formando apêndices ventrais; anteras geralmente oblongas ou linearsubuladas, curtamente rostradas. Ovário súpero ou parcialmente adnato à base do hipanto, glabro, 3-4(-5)-locular. Fruto cápsula. Sementes oblongas a reniformes, com testa foveolada.

Microlicia constitui-se por aproximadamente 130 espécies que ocorrem eminentemente em território brasileiro (Romero 2003). Poucas espécies (ca. 5 spp.) podem ser encontradas na Guiana, Venezuela, Peru e Bolívia. No Brasil, os representantes deste gênero apresentam maior concentração nos Estados de Bahia, Goiás e Minas Gerais, onde ocupam áreas de campos rupestres. Algumas espécies podem ser encontradas em cerrados e campos de altitude dos Estados de Mato Grosso, Mato Grosso do Sul, Paraná e São Paulo e em menor frequiência nos Estados do Amazonas, Maranhão, Pará, Piauí, Rondônia e Rio de Janeiro (Romero \& Martins 2002). No município de Poços de Caldas foram encontradas duas espécies de Microlicia.
Chave de identificação para as espécies de Microlicia de Poços de Caldas

1. Folha oval-oblonga, base obtusa, viloso-tomentosa e com glândulas sésseis em ambas as faces .........2.1. M. euphorbioides

1. Folha ovalada, base atenuada, esparsamente longo-setosa em ambas as faces ........................................... 2.2. M. fulva

2.1. Microlicia euphorbioides Mart., Nov. Gen. et Sp. 3: 107. 1831.

Figura 1B, 2A-C

Subarbustos $1,3 \mathrm{~m}$ alt. Caule e ramos com indumento tomentoso. Folhas sésseis; lâmina 12-25 × 3,5-10 mm, oval-oblonga, base obtusa, ápice agudo, ambas as faces viloso-tomentosas e com glândulas sésseis. Flores solitárias, axilares e/ou terminais. Hipanto $3 \times 2 \mathrm{~mm}$, tubuloso, viloso, glutinoso. Lacínias do cálice $2 \times 1 \mathrm{~mm}$. Pétalas 7,5 ×5 mm, róseas, obovais. Estames ante-sépalos: filete 3,8 $\mathrm{mm}$ compr.; conectivo prolongado $1,5 \mathrm{~mm}$; apêndice $0,8 \mathrm{~mm}$ compr.; anteras 1,8 $\times 0,7 \mathrm{~mm}$, oblongas. Estames antepétalos: filete $3,2 \mathrm{~mm}$ compr.; conectivo prolongado $0,9 \mathrm{~mm}$; apêndice $0,2 \mathrm{~mm}$ compr.; anteras $1,2 \times$ 0,3 mm, oblongas. Ovário súpero, glabro, 3-locular.

Material selecionado: BRASIL. Minas Gerais: Poços de Caldas, Morro do Ferro, 8-III-1983, H.F. Leitão Filho et al. 2009 (UEC).

Microlicia euphorbioides ocorre nos Estados de Mato Grosso, Goiás, Minas Gerais e São Paulo (Rodrigues 2005). No município de Poços de Caldas ocupa campos e locais úmidos.

2.2. Microlicia fulva (Spreng.) Cham., Linnaea 9. 391. 1834. Rhexia fulva Spreng. Neue Entdeck. Pflanzenk. 2: 308. 1820.

Figuras 1C, 2D-F

Subarbustos $0,8 \mathrm{~m}$ alt. Caule e ramos com tricomas ferrugíneo-hirsutos. Folhas subsésseis; lâmina 4-8 × 2-4 mm, ovalada, base atenuada, ápice obtuso a arredondado, esparsamente longo-setosa em ambas as faces . Flores solitárias e/ou terminais. Hipanto $3 \times$ 2,5 mm, campanulado com tricomas setosos. Lacínias do cálice 2,3 × 1,4 mm. Pétalas 6,5-7 × 3,5-4 mm, fortemente purpúreas, obovais. Estames ante-sépalos: filete $3 \mathrm{~mm}$ compr.; conectivo prolongado $2,5 \mathrm{~mm}$; apêndice 0,2 mm compr.; anteras $0,7 \times 0,3 \mathrm{~mm}$, oblongas. Estames antepétalos: filete 2,5 mm compr.; 

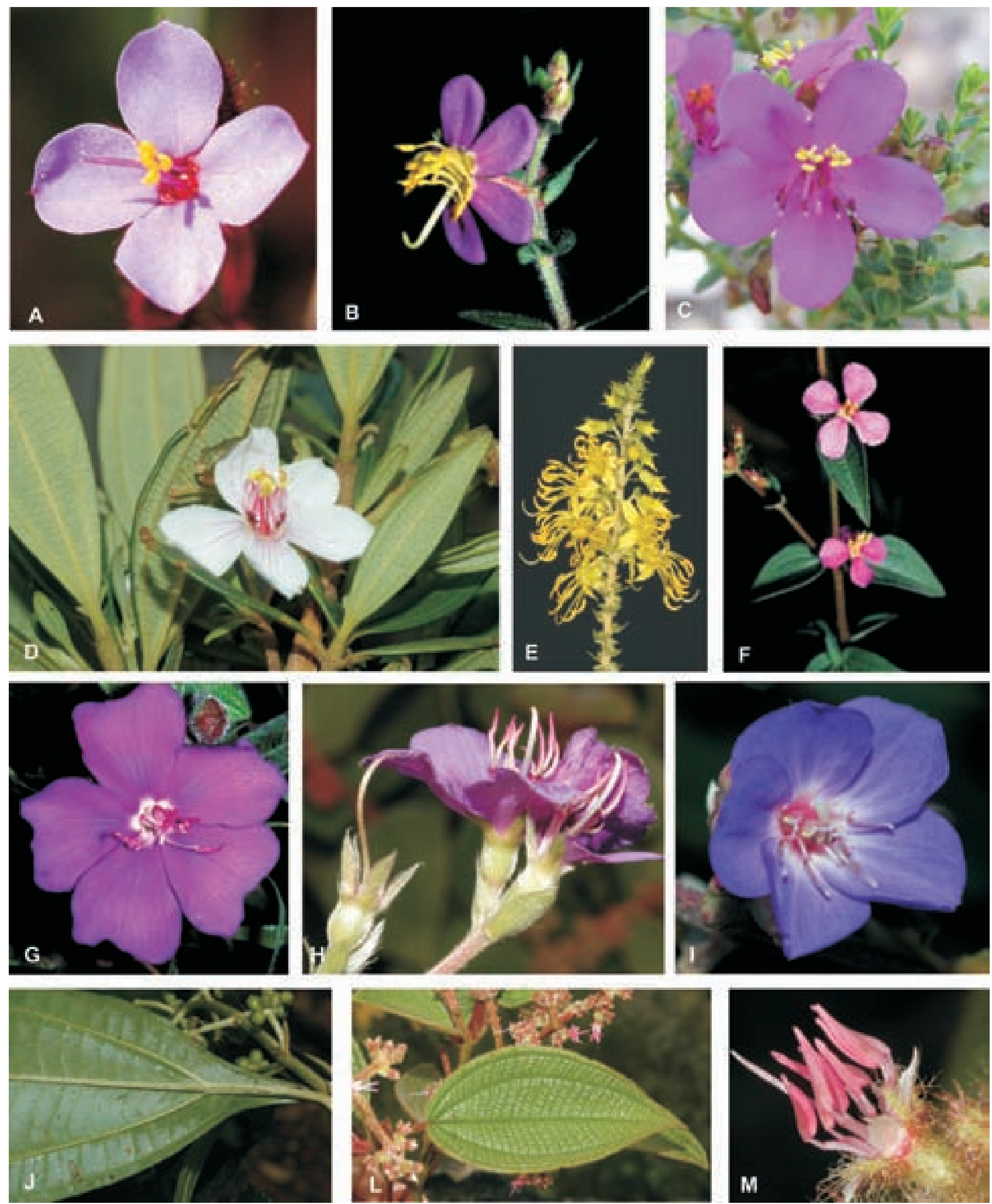

Figura 1. A. Siphanthera cordata. Flor. B. Microlicia euphorbioides. Flor. C. Microlicia fulva. Flor. D. Trembleya parviflora. Folhas e flor. E. Cambessedesia espora subsp. ilicifolia. Inflorescência. F. Tibouchina herbacea. Ramo com flores. G. Tibouchina fothergillae. Flor. H. Tibouchina gracilis. Hipanto e flor. I. Tibouchina heteromalla. Flor. J. Miconia discolor. Base da lâmina foliar. L-M. Leandra lacunosa. L. Ramo. M. Flor. (Fotos: A, B: J.L.M. Aranha Filho; C, E e M: F. Almeda; D, H, I, J e L: F. Michelangeli; G: A.B. Martins; F: M.C.E. Amaral). 
conectivo prolongado $1 \mathrm{~mm}$, apêndice $0,5 \mathrm{~mm}$ compr.; anteras $0,6 \times 0,3 \mathrm{~mm}$, oblongas. Ovário súpero, glabro, 3-locular.

Material selecionado: BRASIL. Minas Gerais: Poços de Caldas, s.d., Regnell II-102 (R).

Material adicional examinado: BRASIL. Minas GeRAIS: Joaquim Felício, Serra do Cabral, 4-V-2003, K.F. Rodrigues et al. 48 (UEC).

Espécie amplamente distribuída no Estado de Minas Gerais. Apresenta poucas coletas citadas para o Estado da Bahia e Distrito Federal (Rodrigues 2005). No município de Poços de Caldas ocupa campos limpos, em solos úmidos.

3. Rhynchanthera DC. in DC., Prodr. 3: 106. 1828.

Rhynchanthera é um gênero neotropical constituído por 15 espécies distribuídas desde a América Central até o Brasil e Paraguai. No Brasil encontram-se 11 espécies que ocorrem preferencialmente em áreas de cerrado e campos rupestres, em locais brejosos e margens de rios (Renner 1990). No município de Poços de Caldas foi coletada apenas Rhynchanthera cordata.

3.1 Rhynchanthera cordata DC. in DC., Prodr. 3: 107. 1828.

Figura 3I-L

Arbustos ou subarbustos 0,5-1,5 m alt. Caule, ramos, folhas e hipanto híspido-glandulosos. Folhas com pecíolo $5 \mathrm{~mm}$ compr.; lâmina 9-14 × 4-8 mm, oval, base cordada, ápice agudo. Inflorescências bíparas. Flores 5-meras. Hipanto $5 \times 3,5 \mathrm{~mm}$, oblongocampanulado. Lacínias do cálice 7-9 × 2-3 mm. Pétalas 18-22 × 12-15 mm, arroxeadas, obovais. Estames 10. Estames ante-sépalos: 5 férteis, sendo um estame bem maior que os demais, estame fértil maior com filete $10,5 \mathrm{~mm}$ compr., conectivo prolongado $12,5 \mathrm{~mm}$, apêndice $2 \mathrm{~mm}$ compr., levemente bilobado, antera $5,5 \times 3 \mathrm{~mm}$, subulada; estames férteis menores com filete $5 \mathrm{~mm}$ compr., conectivo prolongado $5 \mathrm{~mm}$, apêndice $1,5 \mathrm{~mm}$ compr., bilobado, antera $4 \times$ $2 \mathrm{~mm}$, oblonga. Estames antepétalos: 5 estaminódios com $5 \mathrm{~mm}$ compr., anteras ausentes. Ovário súpero, glabro, 3-locular. Fruto cápsula. Sementes obovais.

Material selecionado: BRASIL. Minas Gerais: Poços de Caldas, 27-III-1920, F.C. Hoehne (SP s.n.).

No Brasil, Rhynchanthera cordata é amplamente distribuída desde o Amapá até Santa Catarina.
Ocorre também no Panamá, Guiana, Suriname, Venezuela, Colômbia, Bolívia e Peru (Renner 1990). Em Poços de Caldas, indivíduos desta espécie podem ser encontrados em locais úmidos e brejosos.

4. Trembleya DC. in DC., Prodr. 3: 125. 1828.

Arbustos ou subarbustos, glabros ou pilosos. Folhas sésseis ou pecioladas; lâmina com reticulação evidente na face abaxial, glabra ou pilosa. Flores dispostas em dicásios simples ou compostos, raramente flores isoladas por redução dos dicásios. Flores 5-meras. Hipanto campanulado ou urceolado, glabro ou piloso. Pétalas róseas, purpúreas, brancas ou amarelas, obovais, agudas ou obtusas. Estames 10; conectivo prolongado abaixo das tecas formando apêndices ventrais; anteras oblongas ou linearsubuladas, curtamente rostradas. Ovário súpero ou parcialmente adnato à base do hipanto, 3-5 locular. Fruto cápsula. Sementes ovais ou reniformes, com superfície da testa foveolada.

Trembleya é endêmico do Brasil, sendo constituído por 18 espécies distribuídas especialmente em campos rupestres de Minas Gerais, principalmente ao longo da Serra do Espinhaço. Um menor número de espécies ocorre nos Estados da Bahia, Goiás, Mato Grosso do Sul, Espírito Santo, Rio de Janeiro, São Paulo e Paraná, em cerrados e campos de altitude (Martins 1997). No município de Poços de Caldas foram encontradas duas espécies de Trembleya.

Chave de identificação para as espécies de Trembleya de poços de Caldas

1. Planta não viscosa; folhas discolores 4.1. T. parviflora

1. Planta viscosa; folhas concolores 4.2. T. phlogiformis

4.1. Trembleya parviflora (D. Don) Cogn., in Mart., Fl. Bras. 14 (3): 127. 1885. Meriania parviflora D. Don, Mem. Wern. Soc. 4: 323. 1823. Figuras 1D, 2N

Arbustos 1,5-2 m alt., não viscosos. Folhas com pecíolo 4-8 mm compr.; lâmina 2-4,5 × 1,5-2 cm, elíptica a oblongo-lanceolada, base atenuada, ápice agudo, face adaxial glabrescente, face abaxial com tricomas glandulares sésseis; discolor. Dicásios compostos, axilares. Hipanto $3,4 \times 3 \mathrm{~mm}$, campanulado. Lacínias do cálice $2,5 \times 1,8 \mathrm{~mm}$. Pétalas 8,5-10 $\times 3-5 \mathrm{~mm}$, brancas a róseas, obovais. Estames 
ante-sépalos: filete $4 \mathrm{~mm}$ compr.; conectivo prolongado $3 \mathrm{~mm}$; apêndice $0,3 \mathrm{~mm}$ compr.; anteras $2 \times 0,6 \mathrm{~mm}$, oval-oblongas. Estames antepétalos: filete $2,5 \mathrm{~mm}$ compr.; conectivo prolongado $0,5 \mathrm{~mm}$; apêndice $0,2 \mathrm{~mm}$ compr.; anteras $1,5 \times 0,5 \mathrm{~mm}$, oval-oblongas. Ovário súpero, glabro, 5-locular.

Material selecionado: BRASIL. MinAs GERAIs: Poços de Caldas, Morro do Ferro, 17-VII-81, K. Yamamoto et al. 1113 (UEC).

Trembleya parviflora ocorre nos Estados da Bahia, Goiás, Minas Gerais, Espírito Santo, São Paulo, Rio de Janeiro e Paraná, em campo rupestre, cerrado, campo sujo, transição com matas ciliares, mata atlântica e em campos de altitude (Martins 1997). Em Poços de Caldas esta espécie é pouco freqüente, coletada em campo sujo.

4.2. Trembleya phlogiformis DC. in DC., Prodr. 3: 126. 1828.

Figura 2G-M

Subarbustos 0,8-1,8 m alt., viscosos. Caule, ramos, folhas e hipanto com tricomas glandulares, viscosos. Folhas com pecíolo 4-8 mm compr.; lâmina 2,5-4 × 1,2-1,8 cm, oval a elíptíco-lanceolada, base arredondada a atenuada, ápice agudo; concolor. Dicásios axilares e/ou terminais. Hipanto 3-4 $\times$ 2-3 mm, campanulado. Lacínias do cálice 3-4 × $2 \mathrm{~mm}$. Pétalas 5-9 × 4-4,5 mm, róseas, obovais. Estames antesépalos: filete $3,5 \mathrm{~mm}$ compr.; conectivo prolongado 2,3 mm; apêndice $1 \mathrm{~mm}$ compr.; anteras $1 \times 0,3 \mathrm{~mm}$, oval-oblongas. Estames antepétalos: filete $3 \mathrm{~mm}$ compr.; conectivo prolongado $0,4 \mathrm{~mm}$; apêndice 0,2 mm compr.; anteras 1,3 $\times 0,3 \mathrm{~mm}$, oval-oblongas. Ovário súpero, glabro, 5-locular.

Material selecionado: BRASIL. Minas GeraIs: Poços de Caldas, Campo do Saco, 13-I-1981, L.S. Kinoshita et al. 731 (UEC).

Material adicional examinado: BRASIL. MinAS GERAIS: Joaquim Felício, Serra do Cabral, 4-V-2003, K.F. Rodrigues et al. 63 (UEC).

Trembleya phlogiformis ocorre nos Estados de Bahia, Mato Grosso, Goiás, Minas Gerais, São Paulo, Rio de Janeiro e Paraná (Martins 1997). Especialmente no Estado de Minas Gerais esta espécie é amplamente distribuída. Ao contrário de Trembleya parviflora, indivíduos de Trembleya phlogiformis são bastante frequientes em Poços de Caldas em áreas de campo limpo e campo sujo.

\section{Tribo Melastomae}

5. Acisanthera P. Browne, Hist. Jamaic. 217. 1756.

Acisanthera é um gênero neotropical que ocorre desde o sul do México até a Bolívia e Argentina, compreendendo atualmente ca. 20 espécies que ocupam preferencialmente áreas úmidas e savanas (Wurdack 1962). No Brasil, as espécies deste gênero são amplamente distribuídas, sendo encontradas desde o Pará até Santa Catarina (Wurdack 1983). Atualmente os limites específicos e interespecíficos do gênero estão sendo revisados por Kriebel \& Almeda (Frank Almeda, com. pess.). Acisanthera provavelmente passará a abranger Comolia, como sugerido por Seco (2006). No município de Poços de Caldas foi encontrada apenas uma espécie.

\subsection{Acisanthera alsinefolia Triana, Trans. Linn. Soc.}

London 28: 34. 1871.

Subarbustos 0,8-1 m alt., com tricomas híspidoglandulosos, assim como as folhas e hipanto. Folhas com pecíolo 4-8 mm compr.; lâmina 1,3-2,4×1-1,5 cm, oval a suborbicular, base arredondada a subcordada, ápice agudo. Inflorescência tirsóidea, terminal. Flores 5-meras. Hipanto 3,5-4 × 2-3 mm, oblongocampanulado, 10-costado. Lacínias do cálice $5 \times$ 0,4 mm. Pétalas 7,5-8 × 4-4,5 mm, róseas a magenta, oboval-oblongas. Estames ante-sépalos: filete $3 \mathrm{~mm}$ compr.; conectivo prolongado 2,5-3 $\mathrm{mm}$; apêndice 0,3 mm compr., bífido; anteras $7 \times 0,7 \mathrm{~mm}$, linearsubuladas. Estames antepétalos: filete 2,5 $\mathrm{mm}$ compr.; conectivo prolongado $0,8-1 \mathrm{~mm}$; apêndice $0,2 \mathrm{~mm}$ compr., bífido; anteras $5 \times 0,6 \mathrm{~mm}$, linear-subuladas. Ovário súpero, glabro, 3-locular.

Material selecionado: BRASIL. MinAs GERAIS: Poços de Caldas: III-1875, Regnell III-14 (S).

Acisanthera alsinefolia ocorre nos Estados de Goiás, Minas Gerais, São Paulo, Rio de Janeiro, Santa Catarina e Rio Grande do Sul (Wurdack 1983). Em Poços de Caldas esta espécie ocupa preferencialmente campos de altitude em locais úmidos.

\section{Comolia DC. in DC., Prodr. 3: 114. 1828.}

O gênero Comolia é constituído por 19 espécies que ocorrem no Brasil, Colômbia, Venezuela, Guianas e Suriname. No Brasil o gênero apresenta 10 espécies, das quais sete são endêmicas. Comolia apresenta uma distribuição disjunta entre cerrados e campos rupestres da Região Sudeste e áreas de restinga e savanas 


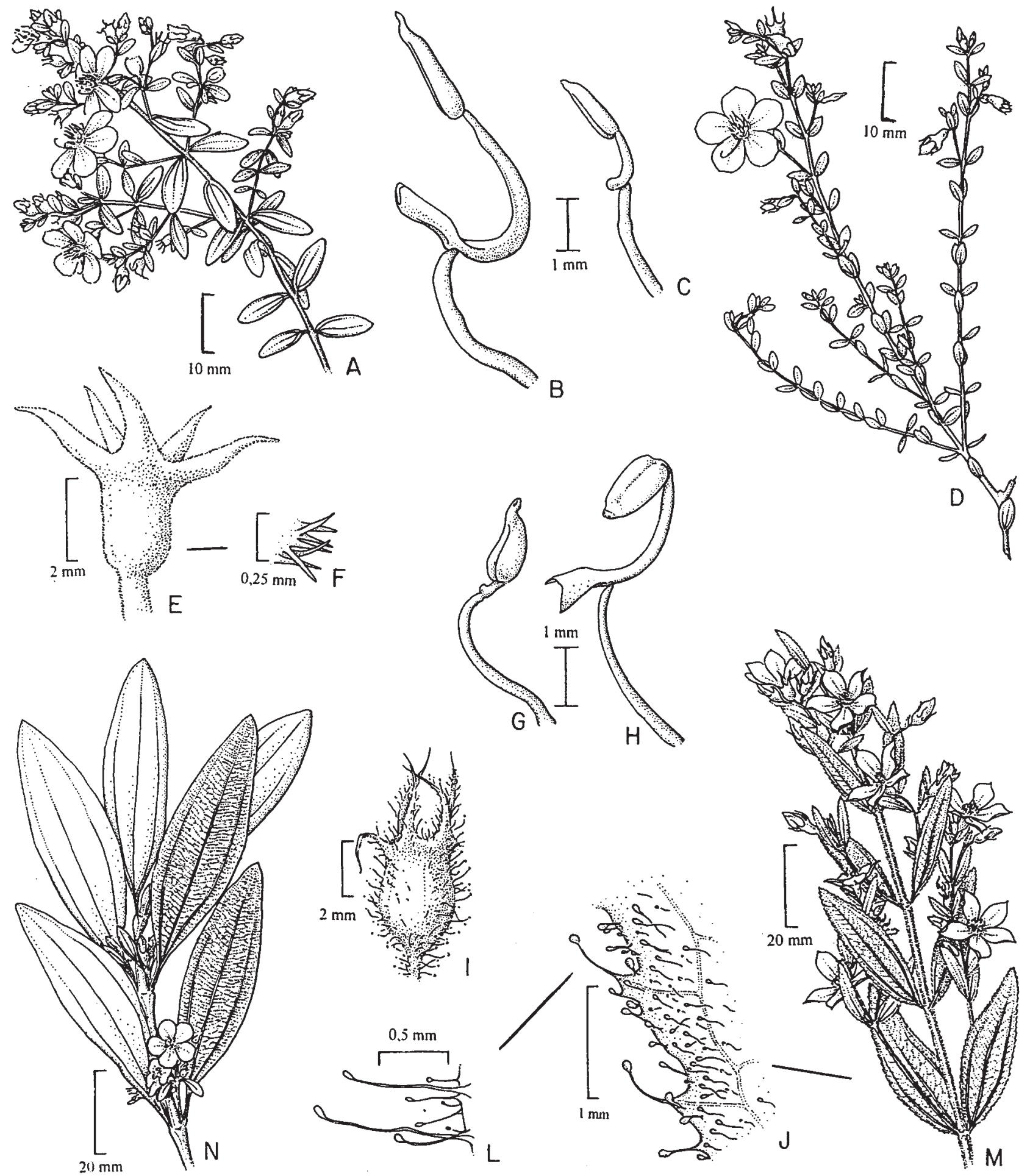

Figura 2. A-C. Microlicia euphorbioides. A. Ramo. B. Estame do ciclo ante-sépalo. C. Estame do ciclo antepétalo. (H.F. Leitão Filho et al. 2009 (UEC)). D-F. Microlicia fulva. D. Ramo. E. Hipanto. F. Detalhe dos tricomas do hipanto. (K.F. Rodrigues et al. 47 (UEC)). G-M. Trembleya phlogiformis. G. Estame antepétalo. H. Estame ante-sépalo. I. Hipanto. J. Detalhe da margem foliar. L. Detalhe dos tricomas da margem foliar. M. Ramo. (K.F. Rodrigues et al. 63 (UEC)). N. Trembleya parviflora. Ramo. (K.Yamamoto et al. 1113 (UEC)). 
arenosas da Região Norte (Seco 2006), não havendo registros para a região sul do Brasil. Estudos recentes indicam uma possível sinonimização entre Comolia e Acisanthera (Seco 2006).

No município de Poços de Caldas foi encontrada apenas uma espécie deste gênero.

6.1. Comolia lanciefolia Triana, Trans. Linn. Soc. London 28: 37. 1871.

Subarbustos 0,5-2,5 m alt., com tricomas híspidoglandulosos. Folhas subsésseis; lâmina 10-20 × 8-15 mm, oval a suborbicular, base arredondada, ápice agudo a apiculado. Panículas terminais. Flores 4-meras. Hipanto 5-5,5 $\times 2 \mathrm{~mm}$, oblongo a urceolado. Lacínias do cálice $2 \times 0,7 \mathrm{~mm}$. Pétalas 9-10×3-5 mm, obovais, púrpuras. Estames ante-sépalos: conectivo prolongado $2-4 \mathrm{~mm}$; apêndice $0,2 \mathrm{~mm}$ compr., bituberculado; anteras $5 \times 0,2 \mathrm{~mm}$, subuladas, levemente falciformes. Estames antepétalos: conectivo prolongado $1 \mathrm{~mm}$; apêndice $0,2 \mathrm{~mm}$ compr., bituberculado; anteras $4 \times 0,1 \mathrm{~mm}$, subuladas, levemente falciformes. Ovário súpero, glabro, 4-locular.

Material selecionado: BRASIL. Minas Gerais: Poços de Caldas, Morro do Ferro, 6-XI-1964, A. Santos et al. s.n. (R s.n.).

Comolia lanciefolia ocupa áreas próximas a cursos d'água em cerrado em Goiás, Distrito Federal e no sul de Minas Gerais (Seco 2006). No município de Poços de Caldas ocorre em áreas de campo limpo, em locais úmidos.

7. Microlepis Miq., Comm. Phytog. 71. 1840.

O gênero Microlepis é endêmico no Brasil sendo constituído por quatro espécies que ocorrem nos Estados de Minas Gerais e São Paulo (Cogniaux 18831885), onde ocupam preferencialmente áreas de cerrado e adjacências.

7.1. Microlepis oleifolia Triana, Trans. Linn. Soc. 28: 36. 1871.

Figura 3A-D

Subarbustos 0,5-0,8 m alt., com tricomas estrelado-furfuráceos. Folhas opostas, pecíolo 3-5 mm compr.; lâmina 4-7 × 1,5-2 cm, lanceolada a oblongolanceolada, base arredondada a atenuada, ápice obtuso. Panículas terminais, multifloras. Flores 5-meras. Brácteas 4-6 × 0,5-3 mm, lanceoladas. Hipanto 4-6 × 2-3 mm, oblongo-campanulado. Lacínias do cálice 2-2,5 × 1,5 mm. Pétalas 10-12 ×
6-8 mm, purpúreas, oblongas. Estames 10. Estames ante-sépalos: filete $3,5 \mathrm{~mm}$ compr., piloso na base; conectivo prolongado $2 \mathrm{~mm}$, ventralmente provido de apêndices afilados; anteras $2 \times 0,6 \mathrm{~mm}$, ligeiramente falciformes. Estames antepétalos: filete $3 \mathrm{~mm}$ compr., piloso na base; conectivo prolongado $4 \mathrm{~mm}$, apêndices pouco conspícuos; anteras $2 \times 0,5 \mathrm{~mm}$, ligeiramente falciformes. Ovário súpero, ápice estrelado-piloso, 5-locular.

Material selecionado: BRASIL. MinAs Gerais: Poços de Caldas, Campo do Saco, 1-IV-1981, J. Semir 930 (UEC).

Microlepis oleifolia é muito próxima de Microlepis quaternifolia Miq., da qual se distingue, segundo Cogniaux (1883-1885), pelas folhas opostas (3-4 verticiladas em $M$. quaternifolia). Este gênero necessita ser revisto para uma melhor delimitação de suas espécies, já que as diversas formas observadas parecem ser apenas variações de uma única espécie. Indivíduos desta espécie ocorrem em Minas Gerais em campos de altitude, em campos rupestres e adjacências. No município de Poços de Caldas esta espécie ocorre em campo sujo.

8. Pterolepis (DC.) Miq., Comm. Phytogr. 2: 72.1840.

Pterolepis é um gênero neotropical constituído por 14 espécies, das quais 11 ocorrem nos cerrados e campos rupestres do Brasil Central, havendo apenas um registro para savanas do Amazonas. Poucas espécies ocorrem em outros países das Américas Central e do Sul (Renner 1994). Em Poços de Caldas foi encontrada apenas uma espécie deste gênero.

8.1. Pterolepis repanda (DC.) Triana, Trans. Linn. Soc. Bot. 28(1): 39. 1871. Osbeckia repanda DC. in DC., Prodr. 3: 141. 1828.

Figura 3E-H

Subarbustos 0,2-0,6 m alt., com tricomas longos, adpresso-estrigosos. Folhas subsésseis; lâmina 2,5-4,5 ×0,8-1,2 cm, oval a oblongo-lanceolada, base arredondada, ápice obtuso a subagudo, densamente revestida por tricomas ferrugíneos, longos, estrigosos, em ambas as faces. Inflorescências cimosas, terminais. Flores 4-meras. Hipanto 6-7 × 3-4 mm, campanulado, revestido por cerdas simples e longas. Lacínias do cálice 6-7 × 1,2-2 mm, alternadas com emergências ramificadas. Pétalas $18-20 \times 12-15 \mathrm{~mm}$, arroxeadas, amplamente obovais. Estames 8. Estames antesépalos: conectivo prolongado $0,4 \mathrm{~mm}$; apêndice 
bilobado; anteras 6-8 $\times 1 \mathrm{~mm}$, linear-subuladas. Estames antepétalos: conectivo prolongado $0,3 \mathrm{~mm}$; apêndice bilobado; anteras 4-6 × 0,8 mm, linearsubuladas. Ovário súpero, piloso no ápice, 4-locular.

Material selecionado: BRASIL. Minas Gerais: Poços de Caldas, 15-II-1862, Regnell I/157 (S).

Pterolepis repanda ocorre na Bolívia, Paraguai e Brasil. Neste último país, esta espécie ocorre na região centro-norte e Sudeste, ocupando matas de galeria, brejos, campo sujo e campo limpo, em altitudes entre 300-1.500 m (Renner 1994). No município de Poços de Caldas ocorre em campo sujo, em áreas úmidas.

9. Siphanthera Pohl ex DC. in DC., Prodr. 3: 114. 1828.

Siphanthera é um gênero sul-americano, constituído por 16 espécies que ocorrem na Venezuela, Colômbia, Bolívia e Brasil (Almeda \& Robinson 1999). Especialmente no Brasil ocorrem 13 espécies que podem ser encontradas em áreas de cerrados e campos rupestres dos Estados de Minas Gerais, Goiás e São Paulo, preferencialmente em locais úmidos. Há também registros de espécies deste gênero para os Estados de Rondônia e Mato Grosso, onde foram encontradas em campos úmidos associados a cerrados. No município de Poços de Caldas apenas uma espécie de Siphanthera foi encontrada.

9.1. Siphanthera cordata Pohl ex DC. in DC. Prodr. 3: 121.1828.

Figuras 1A, 3M-O

Subarbustos 0,3-0,4 m alt. Caule, ramos, folhas e hipanto com tricomas hirsuto-glandulares. Folhas sésseis ou com pecíolo $1 \mathrm{~mm}$ compr.; lâmina 3,8-9 $\times$ 3-7,5 mm, oval, triangular, base cordada, ápice agudo. Glomérulos axilares e terminais. Flores 4-meras. Hipanto 2,8 $\times 1,3 \mathrm{~mm}$, cilíndrico. Lacínias do cálice 2,5 × 1,5 mm. Pétalas 3-4,2 × 3-3,8 mm, arroxeadas ou róseas, obovais. Estames férteis 4, estaminódios 4. Filete $4,2 \mathrm{~mm}$ compr.; conectivo prolongado $0,3 \mathrm{~mm}$; anteras $2 \times 0,5 \mathrm{~mm}$, oblongas, longamente rostradas. Ovário súpero, glabro, 2-locular.
Material selecionado: BRASIL. Minas GeraIs: Poços de Caldas: 1862, Regnell 114 (R).

Siphanthera cordata ocorre nos Estados de Goiás, Mato Grosso, Minas Gerais e São Paulo, geralmente em campos rupestres. No município de Poços de Caldas esta espécie ocupa campos, em áreas úmidas.

10. Tibouchina Aubl., Pl. Guian. 1: 445. 1775.

Árvores, arbustos ou subarbustos, raramente ervas, variadamente pilosos a totalmente glabros. Folhas sésseis ou pecioladas; lâmina de formato variado, geralmente oblongo-lanceolada; freqüentemente com indumento em ambas as faces; 1 -4 pares de nervuras acródromas basais ou suprabasais. Panículas, tirsóides ou dicásios terminais e/ou axilares, ou ainda flores solitárias. Brácteas 2 e bractéolas 2-6, geralmente presentes, involucrais ou raro em caliptra, internamente glabras e externamente com indumento presente. Flores (4-) 5-meras, sésseis ou pediceladas. Hipanto campanulado, tubuloso, ovóide-oblongo ou urceolado, revestido por indumento seríceo, estrigoso ou glanduloso. Lacínias agudas ou obtusas, decíduas ou persistentes, não alternadas com emergências ramificadas. Pétalas em diferentes tonalidades de lilás a roxo, magenta, purpúreas ou brancas, ovais, obovais ou obtriangulares. Estames 10; filetes filiformes, glabros ou pilosos; conectivo usualmente prolongado abaixo das tecas, ventralmente apendiculado; anteras linear-subuladas, raramente oblongas ou truncadas. Ovário súpero ou semi-ínfero, 5-locular, 4-locular nas flores tetrâmeras, tricomas seríceos, raramente glandulares no ápice. Fruto cápsula. Sementes cocleadas ou subcocleadas; superfície da testa tuberculada.

O gênero Tibouchina apresenta cerca de 308 espécies distribuídas desde o México até o norte da Argentina (Guimarães \& Martins 1997). No Brasil ocorrem cerca de 240 espécies que podem ser encontradas em diversas formações vegetais, especialmente na região Sudeste. No município de Poços de Caldas foram encontradas 14 espécies de Tibouchina.

Chave de identificação para as espécies de Tibouchina de Poços de Caldas

1. Erva menor que $0,4 \mathrm{~m}$ alt.; folhas rosuladas 10.7. T. hieracioides

1. Árvores, arbustos ou subarbustos maiores que $0,4 \mathrm{~m}$ alt.; folhas não rosuladas

2. Caule e ramos glabros 10.12. T. sellowiana

2. Caule e ramos diversamente pilosos 
3. Flores 4-meras; brácteas triangulares; ovário 4-locular

4. Lâmina foliar com ambas as faces glanduloso-vilosas 10.5. T. herbacea

4. Lâmina foliar com face adaxial revestida por tricomas setosos e face abaxial vilosa, não glandulosa 10.11. T. sebastianopolitana

3. Flores 5-meras; brácteas oblongas, obovais, ovais, lanceoladas; ovário 5-locular

5. Folha com pecíolo maior que $2 \mathrm{~cm}$ compr.; lacínias do cálice triangulares

6. Brácteas não involucrais; filetes de ambos os ciclos glabros

7. Lâmina foliar amplamente oval, base cordada; hipanto densamente seríceo-estrigoso 10.4. T. gracilis

7. Lâmina foliar lanceolada a oblonga, base aguda a obtusa; hipanto escabro, setuloso-glanduloso 10.10. T. mosenii

6. Brácteas involucrais; filetes de ambos os ciclos com tricomas glandulares

8. Lâmina 5,5-10,8 × 1,5-5 cm; estames ante-sépalos com filete 12-14 mm compr., conectivo prolongado $3,5 \mathrm{~mm}$

10.3. T. frigidula

8. Lâmina $12-20 \times 8-15 \mathrm{~cm}$; estames ante-sépalos com filete $5 \mathrm{~mm}$ compr., conectivo prolongado $1,5 \mathrm{~mm}$ 10.6. T. heteromalla

5. Folha com pecíolo menor que $2 \mathrm{~cm}$ compr.; lacínias do cálice oval-oblongas, obovais a lanceoladas

9. Planta menor que $1 \mathrm{~m}$ alt.; lâmina foliar cordiforme 10.14. T. ursina

9. Planta maior que $1,5 \mathrm{~m}$ alt.; lâmina foliar oval a lanceolada

10. Hipanto com tricomas densamente seríceo-canescentes; estames antepétalos com filete $8 \mathrm{~mm}$ compr. 10.13. T. stenocarpa

10. Hipanto com tricomas estrigosos, setosos, escabros, velutinos, estrelados; estames antepétalos com filete 3-7 mm compr.

11. Lâmina foliar com face adaxial estrigosa, face abaxial serícea

12. Caule e ramos densamente revestidos por tricomas setosos; hipanto estrigoso; apêndices de ambos os ciclos de estames bilobados e providos de tricomas glandulares 10.2. T. fothergillae

12. Caule e ramos com tricomas escabros esparsos; hipanto escabro; apêndices de ambos os ciclos de estames bituberculados, tricomas glandulares ausentes 10.8. T. martialis

11. Lâmina foliar com face adaxial adpresso-setosa ou com tricomas estrelados, face abaxial seríceo-estrelado, com tricomas longos e esparsos, seríceovilosos

13. Lâmina foliar com base obtusa; lacínias do cálice lanceoladas; ovário densamente seríceo no ápice 10.1. T. formosa

13. Lâmina foliar com base levemente atenuada; lacínias do cálice triangulares; ovário setuloso no ápice 10.9. T. moricandiana

10.1. Tibouchina formosa Cogn., in Mart., Fl. Bras. 14(3): 348. 1885.

Arvoreta ou arbustos com 1,5-2 m alt. Caule e ramos revestidos por tricomas seríceo-estrelados. Folhas opostas, não rosuladas; pecíolo $0,3 \mathrm{~cm}$ compr.; lâmina 4,5-6 × 1,5-2 cm, lanceolada, base obtusa, ápice agudo; face adaxial com tricomas curtos, estrelados, face abaxial seríceo-estrelada. Flores 5-meras. Panículas terminais e axilares. Brácteas 4-6 $\times$ 1,2-2 mm, lanceoladas, não involucrais. Hipanto 5,5 $\times$
2,5 mm, oblongo-campanulado, tricomas velutinos, estrelados. Lacínias do cálice $2,5 \times 2 \mathrm{~mm}$, lanceoladas. Pétalas 1-1,5 × 0,5-0,8 cm, roxas, obovais. Estames ante-sépalos: filete $8-10 \mathrm{~mm}$ compr. com tricomas curtos; conectivo prolongado 1-3,5 mm; apêndice bituberculado; anteras $8 \times 0,7 \mathrm{~mm}$, subuladas. Estames antepétalos: filete 6-7 mm compr., subglabro; conectivo prolongado 0,5-1 $\mathrm{mm}$; apêndice bicalcarado; anteras $6 \times 0,5 \mathrm{~mm}$, subuladas. Ovário adnato até a metade ao hipanto, densamente seríceo no ápice, 5-locular. 


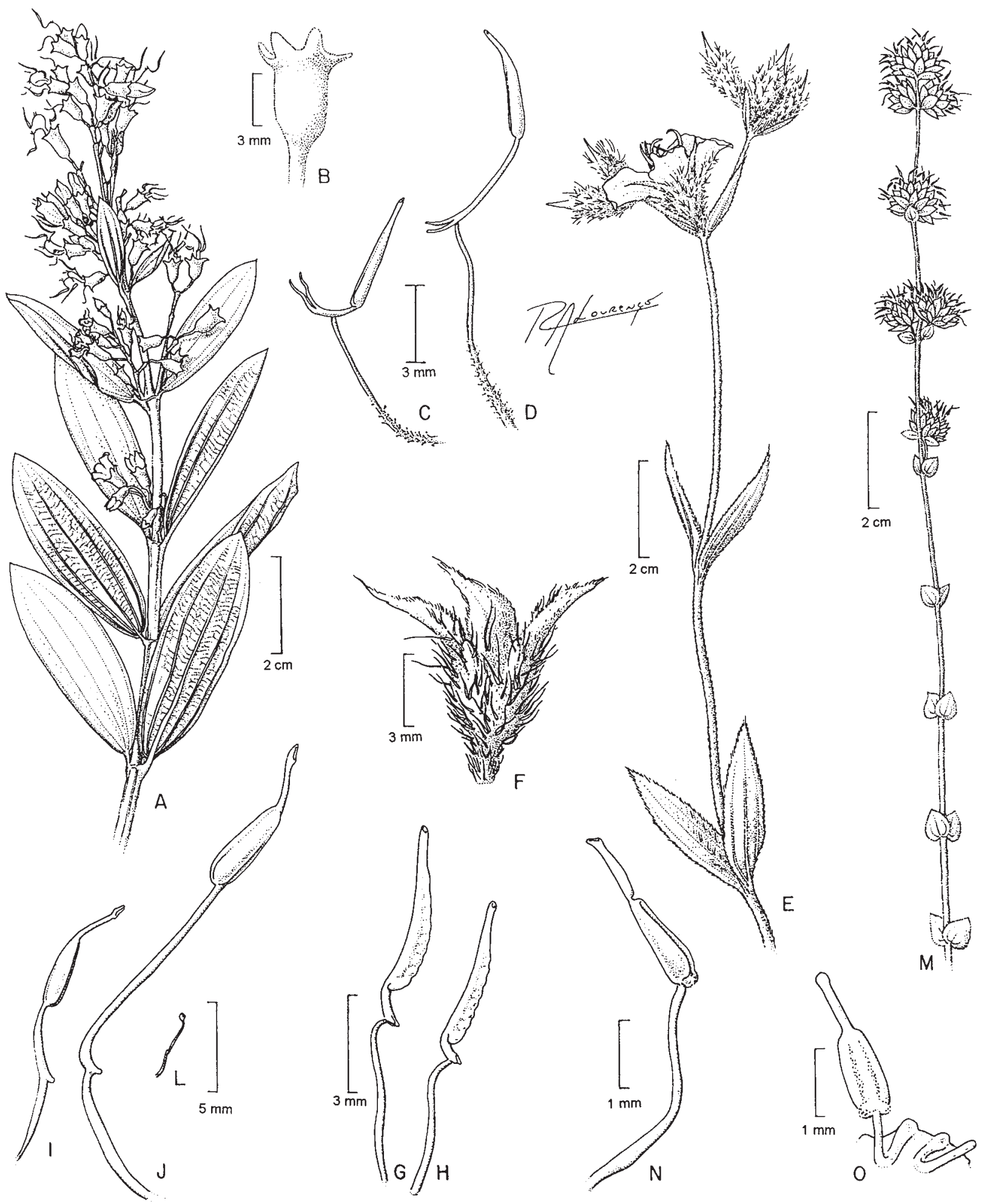

Figura 3. A-D. Microlepis oleifolia. A. Ramo. B. Hipanto. C. Estame antepétalo. D. Estame ante-sépalo. (J. Semir 930 (UEC)). E-H. Pterolepis repanda. E. Ramo. F. Hipanto. G. Estame ante-sépalo. H. Estame antepétalo. (R. Romero \& J.N. Nakajima 660 (UEC)). I-L. Rhynchanthera cordata. I. Estame menor do ciclo ante-sépalo. J. Estame maior do ciclo ante-sépalo. L. Estaminódio. (H.F. Leitão Filho et al. 17278 (UEC)). M-O. Siphanthera cordata. M. Ramo. N. Estame ante-sépalo. O. Estame rudimentar. (F.R. Martins 168 (UEC)). 
Material selecionado: BRASIL. MinAs GERAIs: Poços de Caldas, 19-II-1862, Regnell I-119 (S).

Tibouchina formosa ocorre no Estado de Minas Gerais e, até o momento, é conhecida apenas na região de Poços de Caldas, onde ocorre em áreas de cerrado.

10.2. Tibouchina fothergillae (DC.) Cogn., in Mart., F1. Bras.14(3): 320. 1885. Rhynchanthera fothergillae DC., in DC., Prodr. 3: 108. 1828.

Figuras 1G, 4A-D

Árvore, arvoreta ou arbusto 1,2-5 m alt. Caule e ramos densamente revestidos por tricomas setosos. Folhas opostas, não rosuladas; pecíolo $0,5-2 \mathrm{~cm}$ compr.; lâmina 5-9 × 3,5-4 cm, oval-lanceolada a elíptica, base arredondada, ápice agudo a acuminado; face adaxial levemente estrigosa, face abaxial serícea. Flores 5-meras. Panículas terminais. Brácteas 1,2 $\times$ 0,8-1 cm, ovais, involucrais. Hipanto 4,5-5,5 ×6 mm, campanulado, estrigoso. Lacínias do cálice $1,5 \times 3 \mathrm{~mm}$, triangulares. Pétalas 2,5-3 $\times 2 \mathrm{~cm}$, purpúreo-arroxeadas, obovais. Estames ante-sépalos: filete $8 \mathrm{~mm}$ compr., piloso; conectivo prolongado 2,5 mm; apêndice bilobado, provido de tricomas glandulares; anteras $6,5 \times 1 \mathrm{~mm}$, subuladas. Estames antepétalos: filete $6 \mathrm{~mm}$ compr., piloso; conectivo prolongado 1,5 mm; apêndice bilobado, provido de tricomas glandulares; anteras 5,5 × $1 \mathrm{~mm}$, subuladas. Ovário adnato até a metade ao hipanto, seríceo no ápice, 5-locular.

Material selecionado: BRASIL. MinAs GERAIS: Poços de Caldas, Campo de Santa Rosália: 30-III-1981, J. Semir et al. 904 (UEC).

Tibouchina fothergillae ocorre nos Estados de Minas Gerais, Rio de Janeiro, São Paulo, Paraná e Santa Catarina, ocupando preferencialmente campos, brejos, matas e cerrados. No município de Poços de Caldas ocorre em campo sujo.

10.3. Tibouchina frigidula Cogn., in Mart., Fl. Bras. 14 (3): 328.1885.

Arbustos ou subarbustos 0,5-1 m alt. Caule, ramos, folhas e hipanto esparsamente estrigosos. Folhas verticiladas, raramente opostas, não rosuladas; pecíolo 4 mm compr.; lâmina 5,5-10,8 × 1,5-5 cm, oblonga ou oval-oblonga, base obtusa, ápice agudo. Flores 5-meras. Panículas terminais, multifloras. Brácteas 6,5-7,5 × 3,5-6,5 mm, oblongas, involucrais. Hipanto 6-7 × 5-6 mm, campanulado. Lacínias do cálice 5-6,5 × 2,5-3,5 mm, oval-oblongas. Pétalas 3,5 × 1,5-2 cm, arroxeadas, com base branca, obovais. Estames ante- sépalos: filete 12-14 mm compr., com tricomas glandulares; conectivo prolongado $3,5 \mathrm{~mm}$; apêndice bilobado; anteras 10-12 × 1,3 mm, subuladas. Estames antepétalos: filete $8 \mathrm{~mm}$ compr., com tricomas glandulares; conectivo prolongado $1,5 \mathrm{~mm}$; apêndice bilobado; anteras 7-8 × 0,6 mm, subuladas. Ovário adnato até a metade ao hipanto, setoso no ápice, 5-locular.

Material selecionado: BRASIL. MinAs GeRAIs: Poços de Caldas, Campo de Santa Rosália, 15-X-1980, F.R. Martins et al. 261(UEC).

Tibouchina frigidula ocorre nos Estados de Minas Gerais, São Paulo, Rio de Janeiro, Paraná, Santa Catarina, Rio Grande do Sul, e também na Argentina. Ocupa preferencialmente campos secos e de altitude, locais subúmidos e matas. No município de Poços de Caldas ocorre em campo sujo.

10.4. Tibouchina gracilis (Bonpl.) Cogn., in Mart., Fl. Bras. 14(3): 386. 1885. Rhexia gracilis Bonpl. Monogr. Melast. 2: 138, pl. 52. 1823.

Figura $1 \mathrm{H}$

Erva ou subarbustos até $1 \mathrm{~m}$ alt. Caule e ramos com tricomas estrigoso-setulosos. Folhas opostas, não rosuladas; pecíolo 2-5 mm compr.; lâmina 2-9 $\times$ $1,5-2 \mathrm{~cm}$, lanceolada a oblonga, base aguda a obtusa, ápice agudo a acuminado, ambas as faces adpressoestrigosas. Flores 5-meras. Inflorescências tirsóideas terminais e/ou axilares. Brácteas $6 \times 3 \mathrm{~mm}$, lanceoladas, não involucrais. Hipanto 5-6 × 3-5 mm, campanulado, densamente seríceo-estrigoso. Lacínias do cálice 3-8 × 2-2,5 mm, triangulares. Pétalas 1-2 $\times$ 1-1,5 cm, róseo-arroxeadas, obovais. Estames antesépalos: filete $8,5 \mathrm{~mm}$ compr., glabro; conectivo prolongado 0,5-0,8 $\mathrm{mm}$; apêndice bituberculado; anteras 5,5 $\times 0,7 \mathrm{~mm}$, subuladas. Estames antepétalos: filete $6,5 \mathrm{~mm}$ compr., glabro; conectivo prolongado $2 \mathrm{~mm}$; apêndice bituberculado; anteras 4,5 ×0,6 mm, subuladas. Ovário adnato ao hipanto até a metade, densamente seríceo no ápice, 5-locular.

Material selecionado: BRASIL. MinAs GERAIS: Poços de Caldas, Campo do Saco, 30-XI-1982, H.F. Leitão Filho et al. 1727 (UEC).

Tibouchina gracilis ocorre desde as Guianas até o sul do Brasil, onde é amplamente distribuída. Ocupa preferencialmente vegetações abertas, beira de matas e locais sombreados (Oliveira 2001). No município de Poços de Caldas ocorre em campos e em locais sombreados. 
10.5. Tibouchina herbacea (DC.) Cogn., in Mart., Fl. Bras.14(3): 408. 1885. Rhexia gracilis Bonpl. Monogr. Melast. 138, t. 52. 1823.

\section{Figura 1F}

Subarbustos ou arbustos 0,6-1,5 m alt. Caule, ramos, folhas densamente glanduloso-vilosos. Folhas opostas, não rosuladas; pecíolo 2-5 mm compr.; lâmina 1,5-4,5 × 1-2,5 cm, oval-oblonga, base arredondada, ápice agudo. Flores 4-meras. Inflorescências tirsóideas. Brácteas 3-6 × 2-4 mm, triangulares, não involucrais. Hipanto 3-4 × 1-1,5 mm, oblongo-campanulado, híspido-glanduloso. Lacínias do cálice 3,5 × 1,5 mm, triangulares. Pétalas 8-9 × 4-8 mm, arroxeadas, obovais. Estames ante-sépalos: filete $5 \mathrm{~mm}$ compr., glabro; conectivo prolongado $1 \mathrm{~mm}$; apêndice bituberculado; anteras $7 \times 0,8 \mathrm{~mm}$, subuladas. Estames antepétalos: filete 4,5 $\mathrm{mm}$ compr., glabro; conectivo prolongado 0,5-1,2 mm; apêndice bituberculado; anteras $4 \times$ $0,8 \mathrm{~mm}$, subuladas. Ovário adnato ao hipanto até a metade, ápice glanduloso-piloso, 4-locular.

Material selecionado: BRASIL. Minas GeraIs: Poços de Caldas, 12-II-1861, Regnell II/101 (S).

Tibouchina herbacea ocorre nas Regiões Sudeste e Sul do Brasil, ocupando preferencialmente campos, beira de rios, locais arenosos e sombreados (Oliveira 2001). No município de Poços de Caldas ocorre em campos, próximo a beira de rios.

10.6. Tibouchina heteromalla (D. Don) Cogn., in Mart., Fl. Bras. 14(3): 335. 1885.

Figuras 1I, 4E-M

Arbusto 1,5 m alt. Caule e ramos revestidos por tricomas estrigosos. Folhas opostas, não rosuladas; pecíolo 2,8-6 cm compr.; lâmina $12-20 \times 8-15 \mathrm{~cm}$, cordado-oval a cordiforme, base cordada, ápice agudo, face adaxial estrigoso-serícea, face abaxial vilosa. Flores 5-meras. Panículas terminais. Brácteas 3-4 $\times$ 2-2,5 mm, lanceoladas, involucrais. Hipanto 4,5-5 $\times$ 2,5-3 mm, tubuloso, com tricomas seríceos ou glandulosos. Lacínias do cálice $3 \times 2 \mathrm{~mm}$, lanceoladas. Pétalas 1,3 × 1,2 cm, roxas, obovais. Estames antesépalos: filete $5 \mathrm{~mm}$ compr., com tricomas glandulares na base; conectivo prolongado $1,5 \mathrm{~mm}$; apêndice bilobado; anteras 4,5 ×0,7 mm, subuladas. Estames antepétalos: filete $5,5 \mathrm{~mm}$ compr., com tricomas glandulares na base; conectivo prolongado $1,5 \mathrm{~mm}$; apêndice bilobado; anteras $4 \times 0,5 \mathrm{~mm}$, subuladas. Ovário quase totalmente adnato ao hipanto, densamente setuloso no ápice, 5-locular.
Material examinado: BRASIL. Minas Gerais: Poços de Caldas, 18-III-1920, F.C. Hoehne s.n. (SP s.n.).

Tibouchina heteromalla ocorre no Ceará, Paraíba, Pernambuco, Goiás, Espírito Santo, Minas Gerais, Rio de Janeiro e São Paulo, preferencialmente em campos secos, campos rupestres e cerrados (Guimarães 1997). No município de Poços de Caldas ocupa campo sujo e bordas de matas.

As espécies Tibouchina adenostemon (DC.) Cogn. e Tibouchina multiflora Cogn., também coletadas em Poços de Caldas, foram aqui tratadas como sinônimos de Tibouchina heteromalla, como sugerido por Guimarães (1997).

10.7. Tibouchina hieracioides (DC.) Cogn., in Mart., Fl. Bras. 14(3): 389. 1885. Chaetogastra hieracioides DC. in DC., Prodr. 3: 133. 1828 Figura 4N-Q

Erva 0,2-0,4 m alt. Caule e ramos densamente revestidos por tricomas híspido-vilosos. Folhas opostas, rosuladas; pecíolo 2-3 mm compr.; lâmina 0,3-0,8 $\times$ 0,2-0,3 cm, oval-elíptica a lanceolada, base arredondada, ápice agudo, ambas as faces densamente híspido-vilosas. Flores 5-meras. Inflorescências tirsóideas, terminais. Brácteas $5 \times 3 \mathrm{~mm}$, ovais, não involucrais. Hipanto 7-8 $\times 4-5 \mathrm{~mm}$, campanulado, híspido-viloso. Lacínias do cálice $4-6 \times 3 \mathrm{~mm}$, triangular-lineares. Pétalas 1,8-2,3 $\times 0,9 \mathrm{~cm}$, magenta, irregularmente obtriangulares. Estames ante-sépalos: filete $10 \mathrm{~mm}$ compr., glabro; conectivo prolongado 2,5 mm; apêndice bilobado; anteras $10 \times 1,6 \mathrm{~mm}$, linear-subuladas. Estames antepétalos: filete $7,5 \mathrm{~mm}$ compr., glabro; conectivo prolongado $1,5 \mathrm{~mm}$; apêndice bilobado; anteras 7,5 × 1,3 mm, linear-subuladas. Ovário adnato ao hipanto até a metade, ápice com tricomas glandulares, 5-locular.

Material selecionado: BRASIL. MinAs GERAIS: Poços de Caldas, Campo do Saco, 30-XI-1982, H.F. Leitão Filho et al. 1737 (UEC).

Tibouchina hieracioides ocorre em Minas Gerais, São Paulo e Rio de Janeiro, ocupando campos (Oliveira 2001). No município de Poços de Caldas foi coletada em campo sujo.

10.8. Tibouchina martialis (Cham.) Cogn. in Mart., Fl. Bras. 14(3): 346. 1885. Lasiandra martialis Cham., Linnaea 9: 433. 1834.

Arbustos com até $3 \mathrm{~m}$ alt. Caule e ramos com tricomas escabros esparsos. Folhas opostas, não 
rosuladas; pecíolo 0,2-0,3 cm compr.; lâmina 2,5-4,5 × 0,9-1,8 cm, oblongo-lanceolada, base obtusa, ápice agudo, face adaxial estrigosa, face abaxial serícea. Flores 5-meras. Dicásios terminais e/ou axilares. Brácteas 0,2-0,4×0,2 cm, lanceoladas, não involucrais. Hipanto 5-6 × 3-4 mm, campanulado, escabro. Lacínias do cálice $4 \times 2 \mathrm{~mm}$, oblongas. Pétalas 1,5-1,8 $\times$ 0,7-0,9 cm, roxas ou brancas, obovais. Estames antesépalos: filete 10-12 mm compr., com tricomas longos; conectivo prolongado $2 \mathrm{~mm}$; apêndice bituberculado; anteras $7 \times 1 \mathrm{~mm}$, linear-subuladas. Estames antepétalos: filete 6-7 mm compr., com tricomas longos esparsos; conectivo prolongado 1-1,5 mm; apêndice bituberculado; anteras $5 \times 1 \mathrm{~mm}$, linear-subuladas. Ovário adnato ao hipanto até a metade, densamente seríceo no ápice, 5-locular.

Material selecionado: BRASIL. Minas Gerais: Poços de Caldas, Campo de Galinha, 13-I-1981, L.S. Kinoshita et al. 766 (UEC).

Tibouchina martialis ocorre no Mato Grosso, Goiás, Distrito Federal, Minas Gerais, Rio de Janeiro, São Paulo e Paraná, com distribuição também na Venezuela e Colômbia (Guimarães 1997). Ocupa principalmente campos, campos sujos e beira de matas e adjacências. No município de Poços de Caldas ocorre em campo sujo e em bordas de matas.

Tibouchina pauciflora Cogn., também coletada em Poços de Caldas, foi aqui tratada como sinônimo de Tibouchina martialis, segundo Guimarães (1997).

\subsection{Tibouchina moricandiana Baill., Adansonia 22:} 75. 1877.

Árvores ou arbustos 2-4 m alt. Caule e ramos revestidos por tricomas seríceo-vilosos. Folhas opostas, não rosuladas; pecíolo $0,8 \mathrm{~mm}$ compr.; lâmina 3-8 $\times$ 2-6 cm, lanceolada a oblongo-lanceolada, base levemente atenuada, ápice agudo a longo-acuminado, face adaxial adpresso-setosa, face abaxial com tricomas longos e esparsos, seríceo-vilosos. Flores 5-meras. Dicásios terminais e/ou axilares. Brácteas 12-16 × 7-9 mm, oblongas, involucrais. Hipanto 6-7 $\times$ 3-5 mm, campanulado, estrigoso, setoso. Lacínias do cálice 2-3 $33 \mathrm{~mm}$, triangulares. Pétalas $1,3 \times 1,5 \mathrm{~cm}$, roxas, obovais. Estames ante-sépalos: filete $5 \mathrm{~mm}$ compr., com tricomas curtos na base; conectivo prolongado 1,5 mm; apêndice bilobado; anteras $5 \times$ $1 \mathrm{~mm}$, longo-subuladas. Estames antepétalos: filete $3 \mathrm{~mm}$ compr., com tricomas curtos na base; conectivo prolongado $2 \mathrm{~mm}$; apêndice bilobado; anteras $4,5 \times$
0,8 mm, longo-subuladas. Ovário adnato ao hipanto até a metade, setuloso no ápice, 5-locular.

Material selecionado: BRASIL. MinAs GERAIS: Poços de Caldas, VI-1896, Campos-Novaes 3101 (SP).

Tibouchina moricandiana ocorre nos Estados de Minas Gerais, Rio de Janeiro e São Paulo, principalmente em cerrados. No município de Poços de Caldas foi encontrada em campo sujo.

10.10. Tibouchina mosenii Cogn., in Mart., Fl. Bras. 14(3): 393. 1885.

Subarbustos até $2 \mathrm{~m}$ alt. Caule e ramos com tricomas setulosos e escabros. Folhas opostas, não rosuladas; pecíolo 3-5 cm compr.; lâmina 5-14 × 4-10 cm, amplamente oval, base cordada, ápice agudo, face adaxial dedrítico-setulosa, face abaxial setulosa e escabra. Flores 5-meras. Inflorescência tirsóidea. Brácteas 5,5 × $3 \mathrm{~mm}$, ovais, não involucrais. Hipanto 6-8 $\times 2-4 \mathrm{~mm}$, oblongo-campanulado, escabro, setulosoglanduloso. Lacínias do cálice 3-4 × 1,5-2 mm, triangulares. Pétalas $7,5 \times 5 \mathrm{~cm}$, roxas, obovais. Estames ante-sépalos: filete 6,5 mm compr., glabro; conectivo prolongado $4,5 \mathrm{~mm}$; apêndice bilobado; anteras $9 \times 1 \mathrm{~mm}$, linear-subuladas. Estames antepétalos: filete $10 \mathrm{~mm}$ compr., glabro; conectivo prolongado $1,5 \mathrm{~mm}$; apêndice bilobado, anteras $7 \times$ $0,8 \mathrm{~mm}$, linear-subuladas. Ovário adnato ao hipanto até a metade, setuloso no ápice, 5-locular.

Material selecionado: BRASIL. MinAs GERAIS: Poços de Caldas, s.d., Regnell III/1527 (S).

Tibouchina mosenii apresenta distribuição restrita aos Estados de Minas Gerais e São Paulo, ocupando principalmente campos (vegetações abertas), em locais próximos a fendas rochosas (Oliveira 2001). No município de Poços de Caldas ocorre em campo sujo.

10.11. Tibouchina sebastianopolitana (Raddi) Cogn., in Mart., Fl. Bras. 14(3): 409. 1885. Rhexia sebastianopolitana Raddi Melast. Bras.: 8, t. II, fig. 4. 1828.

Subarbustos 1-1,5 m alt. Caule e ramos esparsamente híspido-setulosos. Folhas opostas, não rosuladas; pecíolo 0,2-0,5 cm compr.; lâmina 4-6,5 × 1,5-3,5 cm, oval a oblonga, base obtusa, ápice agudo a acuminado, face adaxial com tricomas setosos, face abaxial vilosa, não glandulosa. Flores 4-meras. Inflorescências tirsóideas terminais e/axilares. 
Brácteas 2,5 × 1,5 mm, triangulares, involucrais. Hipanto 4,5 × 2,5 mm, ovóide-oblongo, esparsamente glanduloso. Lacínias do cálice 2,5 × 1,5 mm, triangularlineares. Pétalas $8,5 \times 6,5 \mathrm{~mm}$, arroxeadas, obovais. Estames ante-sépalos: filete $5 \mathrm{~mm}$ compr., glabro; conectivo prolongado $1 \mathrm{~mm}$; apêndice bilobado; anteras $5 \times 0,5 \mathrm{~mm}$, linear-subuladas. Estames antepétalos: filete $4 \mathrm{~mm}$ compr., glabro; conectivo prolongado 0,5 mm; apêndice bilobado; anteras 4,5 $\times$ $0,3 \mathrm{~mm}$, linear-subuladas. Ovário adnato até a metade ao hipanto, ápice setuloso, 4-locular.

Material selecionado: BRASIL. Minas Gerais: Poços de Caldas, 11-II-1920, F.C. Hoehne (SP s.n.).

Tibouchina sebastianopolitana ocorre em Minas Gerais, São Paulo, Paraná, Santa Catarina e Rio Grande do Sul, onde ocupa geralmente locais sombreados, úmidos e brejosos (Oliveira 2001). No município de Poços de Caldas ocorre em borda de matas.

10.12. Tibouchina sellowiana Cogn., in Mart., Fl. Bras. 14 (3): 304.1885.

Arvoretas com 0,8-3 m alt. Caule e ramos glabros. Folhas opostas, não rosuladas; pecíolo $0,5-0,7 \mathrm{~cm}$ compr.; lâmina 4,5-6,5 × 2-3 mm, elíptica, base arredondada a atenuada, ápice agudo, face adaxial glabrescente, face abaxial estrigosas com esparsos tricomas adpressos. Flores 5-meras. Panículas terminais e/ou axilares. Brácteas 4,5-5 × 2,8-3,5 mm, oblongas, involucrais. Hipanto 8-10 × 6-7 mm, campanulado a oblongo-campanulado, densamente seríceo-canescente. Lacínias do cálice 5-6 × 3,5-4 mm, triangulares. Pétalas $4 \times 2,5 \mathrm{~cm}$, roxas, obtriangulares. Estames ante-sépalos: filete $4,5 \mathrm{~mm}$ compr., glabro; conectivo prolongado $5 \mathrm{~mm}$; apêndice bilobado; anteras 10-14 × $1 \mathrm{~mm}$, longo-subuladas. Estames antepétalos: filete 3,5 mm compr., glabro; conectivo prolongado 4,5 $\mathrm{mm}$, apêndice bilobado; anteras 7-9 $\times$ $0,8 \mathrm{~mm}$, longo-subuladas. Ovário adnato até a metade ao hipanto, seríceo no ápice, 5-locular.

Material selecionado: BRASIL. Minas Gerais: Poços de Caldas, Campo de Santa Rosália, 21-V-1981, K. Yamamoto et al. 1004 (UEC).

Tibouchina sellowiana ocorre nos Estados de Minas Gerais, São Paulo, Rio de Janeiro, Paraná, Santa Catarina e Rio Grande do Sul, ocupando matas campos e capoeiras. No município de Poços de Caldas ocorre em campo sujo e em matas.
10.13. Tibouchina stenocarpa (DC.) Cogn., in Mart., Fl. Bras. 14(3): 344. 1885. Lasiandra stenocarpa DC. in DC., Prodr. 3: 130.1828.

Arvoreta ou árvore 1,5-5 m alt. Caule e ramos estrigosos. Folhas opostas, não rosuladas; pecíolo 0,6-1,2 cm compr.; lâmina 4,5-12,5 ×2-5 cm, oblongolanceolada, base obtusa, ápice agudo, face adaxial longo-estrigosa, face abaxial serícea com tricomas estrelados. Flores 5-meras. Panículas terminais e/ou axilares. Brácteas $1,2 \times 0,5 \mathrm{~cm}$, obovais, não involucrais. Hipanto 7-11 × 5-6 mm, campanulado, densamente seríceo-canescente. Lacínias do cálice 4-5 ×3 mm, obovais. Pétalas 1,8-3 ×0,7-1,8 cm, roxas, obovais. Estames ante-sépalos: filete $14 \mathrm{~mm}$ compr., densamente revestido por tricomas longos; conectivo prolongado 2,4-4 mm; inapendiculado; anteras $14 \times$ $2 \mathrm{~mm}$, linear-subuladas. Estames antepétalos: filete $8 \mathrm{~mm}$ compr., densamente revestido por tricomas longos; conectivo prolongado 0,5-1 $\mathrm{mm}$; apêndice bituberculado; anteras $9 \times 0,8 \mathrm{~mm}$, linear-subuladas. Ovário adnato até a metade ao hipanto, seríceo no ápice, 5-locular.

Material selecionado: BRASIL. MinAs Gerais: Poços de Caldas, Morro do Ferro, 8-II-1983, H.F. Leitão Filho et al. 2039 (UEC).

Tibouchina stenocarpa ocorre no Pará, Rondônia, Bahia, Distrito Federal, Goiás, Mato Grosso, Minas Gerais, São Paulo e Rio de Janeiro, onde ocupa principalmente cerrado e adjacências. Ocorre também na Bolívia e no Paraguai (Guimarães 1997). No município de Poços de Caldas foi coletada em borda de matas.

10.14. Tibouchina ursina (Cham.) Cogn., in Mart., Fl. Bras. 14(3): 351. 1885. Lasiandra ursina Cham., Linnaea 9: 443. 1834.

Subarbustos 0,5-0,8 m alt. Caule e ramos densamente revestidos por tricomas híspidos, glandulosos. Folhas opostas, não rosuladas; pecíolo 0,2-0,5 cm compr.; lâmina 5,5-7,5 × 3-4,5 cm, cordiforme, base cordada, ápice agudo, ambas as faces seríceas. Flores 5-meras. Panículas, terminais. Brácteas 1,5-1,7 × 0,6-0,9 cm, lanceoladas, não involucrais. Hipanto $8-10 \times 5-6 \mathrm{~mm}$, tubuloso, densamente seríceo. Lacínias do cálice 8-12 × 2-3 mm, lanceoladas. Pétalas 1,8-2 × 1,5 cm, roxas, obovais. Estames ante-sépalos: filete $9 \mathrm{~mm}$ compr., glabro; conectivo prolongado $1,5 \mathrm{~mm}$; apêndice bituberculado; anteras $10 \times 1 \mathrm{~mm}$, linear-subuladas. Estames 

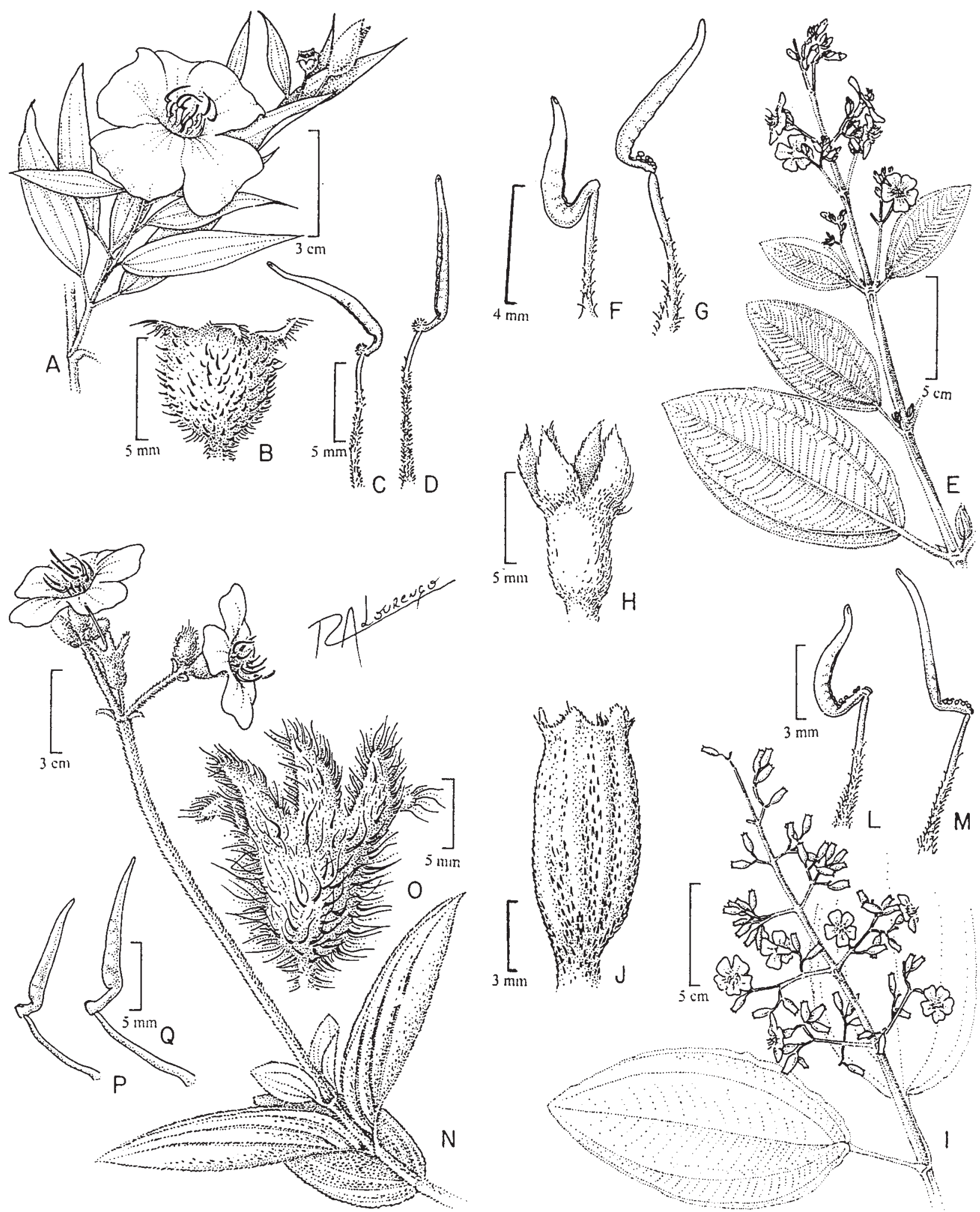

Figura 4. A-D. Tibouchina fothergillae. A. Ramo. B. Hipanto. C. Estame ante-sépalo. D. Estame antepétalo. (K. Yamamoto et al. 1078-A (UEC)). E-M. Tibouchina heteromalla. E. Ramo. F. Estame antepétalo. G. Estame ante-sépalo. H. Hipanto. (J. Semir et al. 19552 (UEC). I. Ramo. J. Hipanto. L. Estame antepétalo. M. Estame ante-sépalo. (Aranha Filho et al. 14 (UEC)). N-Q. Tibouchina hieracioides. N. Ramo. O. Hipanto. P. Estame ante-sépalo. Q. Estame ante-sépalo. (H.F. Leitão Filho et al. 1737 (UEC)). 
antepétalos: filete $11 \mathrm{~mm}$ compr., glabro; conectivo prolongado $1,2 \mathrm{~mm}$; apêndice bituberculado; anteras $10 \times 0,8 \mathrm{~mm}$, linear-subuladas. Ovário adnato até a metade ao hipanto, ápice glanduloso-piloso, 5-locular.

Material selecionado: BRASIL. Minas Gerais: Poços de Caldas: Morro do Ferro: 6-III-1964, M. Emmerich 1948 (UEC).

Tibouchina ursina ocorre nos Estados de Minas Gerais, São Paulo, Paraná e Santa Catarina, onde ocupa principalmente beira de brejo (Guimarães 1997). No município de Poços de Caldas essa espécie foi coletada em campos úmidos, em locais sombreados.

11. Leandra Raddi., Mem. Mat. Fis. Soc. Modena, Pt. Mem. Fis. 18: 385. 1820.

Árvores, arbustos, subarbustos, raro lianas ou epífitas. Caule e ramos com indumento variado. Folhas geralmente pecioladas; glabras ou mais freqüentemente pilosas; 3-7(-9) nervuras acródromas basais ou suprabasais, com ou sem domácias. Inflorescências terminais ou às vezes pseudo-axilares. Brácteas e bractéolas persistentes ou não. Flores 4-5(-6) meras; sésseis ou pediceladas. Hipanto tubuloso, urceolado, oblongo ou campanulado, geralmente piloso. Cálice duplo, lacínias persistentes, agudas a acuminadas, internas membranáceas e externas com a mesma consistência do hipanto. Pétalas brancas a róseas ou levemente amareladas, oval-triangulares a linearlanceoladas, ápice agudo a acuminado, reflexas ou eretas. Estames em número duplo ao das pétalas, isomorfos, subisomorfos ou dimorfos; filetes glabros; conectivo prolongado ou não abaixo das tecas; apêndice dorsal ausente ou inconspícuo; anteras retilíneas ou extrorsamente curvas, uniporadas. Ovário parcial ou totalmente adnato ao hipanto; glabro ou mais frequientemente piloso, 2-6-locular; estilete glabro ou piloso; estigma punctiforme ou capitado. Fruto baga. Sementes numerosas, obpiramidais, oblongo-obovadas.

O gênero Leandra apresenta cerca de 200 espécies que ocorrem desde o sul do México até o norte da Argentina (Souza \& Baumgratz 2005). No Brasil, o gênero é amplamente distribuído, sendo encontrado em cerrados, campos rupestres, florestas higrófilas e mesófilas e áreas de restinga. O último estudo dedicado a Leandra foi realizado por Cogniaux (1886-1888) e, após esta data, nenhum tratamento taxonômico abrangente foi dispensado ao grupo, dificultando na maioria das vezes a identificação de muitas de suas espécies. No município de Poços de Caldas foram encontradas 16 espécies de Leandra.

1. Inflorescências tirsóideas, glomeruladas

2. Folha com base aguda a cuneada, ápice agudo a acuminado, face abaxial setulosa; ovário 4locular 11.9. L. melastomoides

2. Folha com base arredondada ou cordada, ápice agudo, obtuso, apiculado; face abaxial vilosa, furfuráceo-estrelada; ovário 3-locular

3. Brácteas ovais; hipanto com tricomas hirtelos e furfuráceo-estrelados esparsos ... 1.10. L. polystachya

3. Brácteas linear-subuladas; hipanto revestido por tricomas dendríticos, setulosos, posteriormente glabrescentes

4. Caule e ramos com tricomas dendríticos, setulosos, posteriormente glabrescentes

11.2. L. carassana

4. Caule e ramos com tricomas hirtelos, velutinos ou furfuráceo-estrelados

5. Arbustos 1,5-2,5 m alt.; folha elíptica a lanceolada; conectivo não prolongado, inapendiculado. 11.1. L. aurea

5. Subarbustos a arbustos $0,3-0,8 \mathrm{~m}$ alt.; folha ovalada a suborbiculada; conectivo prolongado, calcarado no dorso

11.4. L. erostrata

1. Inflorescências tirsóideas, fasciculadas ou subfasciculadas

6. Folhas com nervuras acródromas basais

7. Caule, ramos, folhas e hipanto totalmente glabros 11.6. L. glabrata

7. Caule, ramos, folhas e hipanto com indumento variável

8. Lâmina foliar com ápice obtuso, margem levemente serreada; 3-4 pares de nervuras acródromas basais 11.13. L. rigida

8. Lâmina foliar com ápice agudo, acuminado, margem inteira, crenulada, levemente serreada; 1-2 pares nervuras acródromas basais 
9. Brácteas 5,5 × 2,5 mm, ovais; hipanto tubuloso a suburceolado; ovário glabro

11.7. L. lacunosa

9. Brácteas 1,5-2 ×0,8 mm, linear-subuladas; hipanto campanulado; ovário setuloso

no ápice 11.8. L. lancifolia

6. Folhas com nervuras acródromas suprabasais

10. Pétalas amarelas, róseas

11. Lâmina foliar com face adaxial glabra e setosa nas nervuras e face adaxial com tricomas hirsutos, furfuráceo-estrelados; pétalas amarelas 11.5. L. gardneriana

11. Lâmina foliar com ambas as faces revestidas por tricomas setulosos, furfuráceoestrelados; pétalas róseas 11.16. L. xanthostachya

10. Pétalas brancas

12. Caule e ramos com tricomas hirtelo-vilosos; hipanto densamente revestido por tricomas seríceos; conectivo prolongado $0,4 \mathrm{~mm}$, calcarado no dorso..... 11.14. L. sericea

12. Caule e ramos com tricomas, hirtelos, hirsutos, furfuráceo-estrelados; hipanto densamente revestido por tricomas papilosos e estrelados, furfuráceo-estrelados, hirtelos, hirtelo-vilosos; conectivo não prolongado, não calcarado no dorso

13. Lâmina foliar elíptica, base aguda; cálice com lacínias externas 3,5 mm compr.; filetes 3-4,5 mm compr. 11.11. L. purpurascens

13. Lâmina foliar oval, amplamente oval, oblonga ou ovada; cálice com lacínias externas menor que 3,5 mm compr.; filetes 1,5-2,5 mm compr.

14. Folha com pecíolo maior que $4,5 \mathrm{~cm}$ compr.; margem inteira; hipanto campanulado 11.3. L. dispar

14. Folha com pecíolo menor que $4 \mathrm{~cm}$ compr.; margem serreado-ciliada, crenulado-ciliada; hipanto tubuloso

15. Lâmina foliar oval, margem levemente serreado-ciliada; anteras oblongas; ovário esparsamente setuloso no ápice 11.12. L. regnellii

15. Lâmina foliar oblonga ou ovada, margem crenulado-ciliada; ovário glabro

11.15. L. xanthocoma

11.1. Leandra aurea (Cham.) Cogn., in Mart., Fl. Bras. 14(4): 143. 1886. Clidemia aurea Cham, Linnaea 10: 47. 1836.

Arbustos 1,5-2,5 m alt. Caule, ramos, folhas e hipanto densamente velutino-pilosos e esparsamente furfuráceo-estrelados. Folhas com pecíolo 1,5-2,5 cm compr.; lâmina 4,5-12 × 2,5-6,5 cm, elíptica a lanceolada, base cordada a arredondada, ápice agudo a acuminado, margem inteira ou crenulado-ciliada; 2-3 pares de nervuras acródromas basais. Inflorescências tirsóideas, glomeruladas. Brácteas $6 \times 1,5 \mathrm{~mm}$, linearlanceoladas. Flores 5-meras. Hipanto 4-5 × $3 \mathrm{~mm}$, tubuloso. Lacínias do cálice: as externas $2,5 \times 0,5 \mathrm{~mm}$, as internas $0,8 \times 0,3 \mathrm{~mm}$. Pétalas 4-4,5 × 1,5-2 $\mathrm{mm}$, brancas, oval-triangulares. Estames com filetes 3-5 mm compr., conectivo não prolongado, inapendiculado; anteras 2-3,5 ×0,4-0,5 mm, subuladas. Ovário adnato até a metade ao hipanto, piloso no ápice, 3-locular.

Material selecionado: BRASIL. Minas GeRAIs: Poços de Caldas, 9-IX-1864, Regnell II-108 (R).

Leandra aurea ocorre nos Estados da Bahia, Minas Gerais, Rio de Janeiro, São Paulo, Paraná Santa Catarina e Rio Grande do Sul, pode também ser encontrada na Bolívia. Ocupa preferencialmente matas, cerrados, campos rupestres, locais úmidos e sombreados. No município de Poços de Caldas foi encontrada em bordas de matas.

11.2. Leandra carassana (DC.) Cogn., in Mart., Fl. Bras. 14(4): 120. 1886. Clidemia carassana DC. in DC., Prodr. 3: 162. 1828.

Árvores a arbustos 1-6 m alt. Caule, ramos, folhas e hipanto revestidos por tricomas híspido-dendríticos, setulosos, posteriormente glabrescentes. Folhas com pecíolo 3-10 cm compr.; lâmina 7,5-20 × 4-12 cm, elíptica a oval, base arredondada a subcordada, ápice agudo a acuminado, margem crenulado-ciliada; 2-3 pares de nervuras acródromas suprabasais. Inflorescências tirsóideas, glomeruladas. Brácteas 2-3 
$\times$ 0,5-0,6 mm, linear-subuladas. Flores (4-)5-meras. Hipanto $4,2 \times 2 \mathrm{~mm}$, campanulado a urceolado. Lacínias do cálice: as externas $2 \times 1 \mathrm{~mm}$, as internas $0,8 \times 0,3 \mathrm{~mm}$. Pétalas $3,4 \times 2,5 \mathrm{~mm}$, brancas, lanceolado-subuladas. Estames com filetes 2,5-4,5 mm compr.; conectivo não prolongado, inapendiculado; anteras 3,5-4 × 0,5-0,7 mm, subuladas. Ovário adnato até a metade ao hipanto, setoso no ápice, 3-locular.

Material selecionado: BRASIL. Minas Gerais: Poços de Caldas, Campo de Santa Rosália, 17-XI-1980, G.J. Shepherd 432 (UEC).

Leandra carassana ocorre nos Estados de Minas Gerais, Rio de Janeiro, São Paulo, Paraná, Santa Catarina e Rio Grande do Sul, sendo encontrada em campos e matas. No município de Poços de Caldas ocorre em matas.

11.3. Leandra dispar (Gardn.) Cogn., in Mart., Fl. Bras. 14(4):117. 1886. Clidemia dispar Gardn. London J. Bot. 2: 345. 1843.

Arbustos 1,5-2,5 m alt. Caule e ramos com tricomas furfuráceo-estrelados. Folhas com pecíolo 4,5-6,5 cm compr.; lâmina 10-13 × 6-8,5 cm, amplamente oval, base arredondada a assimétrica, ápice longo-acuminado, margem inteira; face adaxial esparsamente estrigosa, face abaxial canescentevilosa; 2-3 pares de nervuras acródromas suprabasais. Inflorescências tirsóideas, subfasciculadas. Brácteas 2-3 $\times$ 0,5-0,7 mm, lineares. Flores 5-meras. Hipanto 3,5 $\times 1,5-2 \mathrm{~mm}$, campanulado, densamente revestido por tricomas papilosos e estrelados. Lacínias do cálice: as externas $1,3 \times 0,5 \mathrm{~mm}$, as internas $0,8 \times 0,3 \mathrm{~mm}$. Pétalas $3 \times 1,8 \mathrm{~mm}$, brancas, linear-lanceoladas. Estames com filetes 2-2,5 mm compr., conectivo não prolongado; apêndices inconspícuos; anteras 3-3,5 × 0,5-0,7 mm, linear-subuladas. Ovário adnato até a metade ao hipanto, esparsamente setoso no ápice, 3-locular.

Material selecionado: BRASIL. Minas Gerais: Poços de Caldas, 20-III-1874, Regnell III-24 (S).

Leandra dispar pode ser encontrada nos Estados de Minas Gerais, Rio de Janeiro e São Paulo, ocupando beira de matas. No município de Poços de Caldas ocorre em matas e em campo sujo.

11.4. Leandra erostrata (DC.) Cogn., in Mart., Fl. Bras. 14(4): 139. 1886. Clidemia erostrata DC. in DC., Prodr. 3: 160. 1828.
Subarbustos a arbustos 0,3-0,8 m alt. Caule, ramos e hipanto revestidos por tricomas hirtelos, furfuráceo-estrelados. Folhas com pecíolo3-8 mm compr.; lâmina 3-7 ×2-4,5 cm, ovalada a suborbiculada, base arredondada a cordada, ápice obtuso, apiculado, margem crenulada; face adaxial moderadamente revestida por tricomas setulosos, furfuráceoestrelados, face abaxial com tricomas vilosos, furfuráceo-estrelados; 2-3 pares de nervuras acródromas basais. Inflorescências tirsóideas, glomeruladas. Brácteas $3,5 \times 2 \mathrm{~mm}$, lanceoladas ou oblongo-lanceoladas. Flores 5-meras. Hipanto 3-4 $\times$ 2,5 mm, tubuloso. Lacínias do cálice: as externas 1,5 $\times$ $0,6 \mathrm{~mm}$, as internas $0,4 \times 0,2 \mathrm{~mm}$. Pétalas $3 \times 0,7 \mathrm{~mm}$, róseas, lanceolado-subuladas. Estames com filetes 2,5-3 mm compr., conectivo prolongado, calcarado no dorso; anteras $2,4 \times 0,6 \mathrm{~mm}$, subuladas. Ovário adnato até a metade ao hipanto, piloso no ápice, 3-locular.

Material examinado: BRASIL. Minas Gerais: Poços de Caldas, Campo de Santa Rosália, 17-XI-1980, G.J. Shepherd 434 (UEC).

Leandra erostrata distribui-se desde o Estado do Amazonas até o Rio Grande do Sul, ocorrendo também na Bolívia e Argentina. No Brasil esta espécie ocupa campos e cerrados. No município de Poços de Caldas ocorre em campo sujo.

11.5. Leandra gardneriana Cogn., in Mart., Fl. Bras. 14(4): 93.1886.

Subarbustos a arbustos 0,5-1,8 m alt. Caule, ramos e face abaxial das folhas com tricomas hirsutos, furfuráceo-estrelados. Folhas com pecíolo 0,5-3 cm compr.; lâmina $8-12 \times 2-5 \mathrm{~cm}$, oval a elíptica, base obtusa a arredondada, ápice agudo ou acuminadoapiculado, margem inteira a crenulado-ciliada; face adaxial esparsamente setuloso-setosa; 1-2 pares de nervuras acródromas suprabasais. Inflorescências tirsóideas, subfasciculadas. Brácteas 1,5-3,5 × 0,5-2 mm, elípticas. Flores 5-meras. Hipanto 3,2 $\times$ $3 \mathrm{~mm}$, tubuloso a suburceolado, esparsamente furfuráceo-estrelado. Lacínias do cálice: as externas 2-5 $\times 0,5-0,8 \mathrm{~mm}$, as internas 0,4-0,8 $\times 0,2-0,3 \mathrm{~mm}$. Pétalas 3,5-4 × 1,5-2 mm, amareladas, triangularsubuladas. Estames com filetes $3 \mathrm{~mm}$ compr.; conectivo não prolongado, apêndice inconspícuo; anteras 3,2 $\times 0,4 \mathrm{~mm}$, linear-subuladas. Ovário quase totalmente adnato ao hipanto, glabro, 3-locular.

Material selecionado: BRASIL. Minas Gerais: Poços 
de Caldas, XI-1854, Lindberg 324 (S).L e a $n$ d $r$ a gardneriana ocorre nos Estados de Minas Gerais, Espírito do Santo, Rio de Janeiro e São Paulo. Ocupa preferencialmente campos úmidos, matas, matas ciliares, capões de matas e locais sombreados. No município de Poços de Caldas cresce em matas e no campo sujo.

11.6. Leandra glabrata (Bunbury) Cogn., in Mart., Fl. Bras. 14(4): 172. 1886. Clidemia glabrata Bunbury, Proc. Linn. Soc. 1: 108. 1841.

Arbustos 2-3 m alt. Caule, ramos, folhas e hipanto totalmente glabros. Folhas com pecíolo 1-2 cm compr.; lâmina 8-9 × 3-4 cm, lanceolada, base arredondada, ápice agudo, acuminado, margem inteira; 1-2 pares de nervuras acródromas basais. Inflorescências tirsóideas, subfasciculadas. Brácteas 4,5-5,5 $\times$ 0,8-1 mm, lanceoladas. Flores 5-meras. Hipanto 3-3,5 × 2,5 mm, tubuloso-urceolado. Lacínias do cálice: as externas $2,3 \times 0,7 \mathrm{~mm}$, as internas $1,8 \times 0,5 \mathrm{~mm}$. Pétalas $3,5 \times 1,3 \mathrm{~mm}$, amareladas, lanceoladoacuminadas. Estames com filetes 2,8-3,2 mm compr.; conectivo não prolongado, inapendiculado; anteras 2,5 $\times 0,5 \mathrm{~mm}$, atenuadas no ápice. Ovário adnato até a metade ao hipanto, glabro, 3-locular.

Material selecionado: BRASIL. MinAs GeraIs: Poços de Caldas, 27-XI-1864, Regnell III/543 (S).

Leandra glabrata pode ser encontrada nos Estados de Goiás, Minas Gerais e São Paulo, ocupando beira de matas e locais sombreados. No município de Poços de Caldas ocorre em matas.

11.7. Leandra lacunosa Cogn., in Mart., Fl. Bras. 14(4): 138. 1886.

Figura 1L-M

Arbustos 0,5-1,5 m alt. Caule e ramos com tricomas hirsutos esparsos, entremeados por tricomas dendríticos. Folhas com pecíolo 1-2,5 cm compr.; lâmina 7-15 × 3-9 cm, oval a oval-lanceolada, base arredondada, ápice agudo, acuminado, margem serrilhado-ciliada; face adaxial densamente estrigosa, furfurácea ao longo das nervuras, face abaxial moderadamente revestida por tricomas dendríticos, sobretudo nas nervuras principais; 2 pares de nervuras acródromas basais. Inflorescências tirsóideas, fasciculadas. Brácteas $5,5 \times 2,5 \mathrm{~mm}$, ovais. Flores 5-meras. Hipanto $5 \times 3,5 \mathrm{~mm}$, tubuloso a suburceolado, com tricomas dendríticos e vilosos. Lacínias do cálice: as externas $1,5 \times 0,7 \mathrm{~mm}$, as internas $1,3 \times 0,3 \mathrm{~mm}$.
Pétalas $4 \times 1,5 \mathrm{~mm}$, brancas, triangular-lanceoladas. Estames com filetes 2-2,5 mm compr.; conectivo espessado no dorso, formando calcar curto; anteras 4-4,5 × 0,5-0,7 mm, subuladas. Ovário adnato até à metade ao hipanto, glabro, 3-locular.

Material selecionado: BRASIL. Minas Gerais: Poços de Caldas, Campo de Santa Rosália, 24-XI-1982, A.C. Gabrielli 1668 (UEC).

Leandra lacunosa foi coletada no Distrito Federal e nos Estados de Minas Gerais, São Paulo e Paraná, (provavelmente ocorre também em Goiás), onde é encontrada em campos, beira de matas e cerrados. No município de Poços de Caldas cresce em matas e campo sujo.

11.8. Leandra lancifolia Cogn., in Mart., Fl. Bras. 14(4): 146. 1886.

Arbustos 1-2 m alt. Caule e ramos esparsamente pilosos. Folhas com pecíolo 1,5-2,5 cm compr.; lâmina 4-6 × 2-3 cm, oval a oblongo-lanceolada, base arredondada a levemente cordada, ápice agudo, margem crenulada; glabrescente em ambas as faces; 2 pares de nervuras acródromas basais. Inflorescências tirsóideas, subfasciculadas. Brácteas 1,5-2 $\times 0,8 \mathrm{~mm}$, linear-subuladas. Flores 5-meras. Hipanto $3 \times 2 \mathrm{~mm}$, campanulado, com tricomas vilosos. Lacínias do cálice: as externas $2 \times 0,7 \mathrm{~mm}$, as internas $1 \times 0,5 \mathrm{~mm}$. Pétalas 4-4,5 ×0,7-1 mm, róseas, lanceoladas. Estames com filetes 2-5,5 mm compr.; conectivo não prolongado, inapendiculado; anteras 3,5-4 × 0,4-0,5 mm, subuladas. Ovário adnato até a metade ao hipanto, setuloso no ápice, 3-locular.

Material selecionado: BRASIL. MinAs Gerais: Poços de Caldas, Campo de Santa Rosália, 6-XI-1980, G.J. Shepherd 403 (UEC).

Leandra lancifolia é aparentemente endêmica no Estado de Minas Gerais, onde pode ser encontrada em campos secos e campos rupestres. No município de Poços de Caldas ocorre em campo sujo de altitude.

11.9. Leandra melastomoides Raddi, Mem. Soc. Ital.

Fis. 18: 386. 1820.

Figura $5 \mathrm{H}$

Arbustos a arvoretas 1-4,5 m alt. Caule e ramos com tricomas híspido-estrigosos. Folhas com pecíolo 0,6-1,5 cm compr.; lâmina 5-15 × 2-6 cm, elíptica, base aguda a cuneada, ápice agudo a acuminado, margem inteira a crenulada; face adaxial estrigosa, face abaxial 

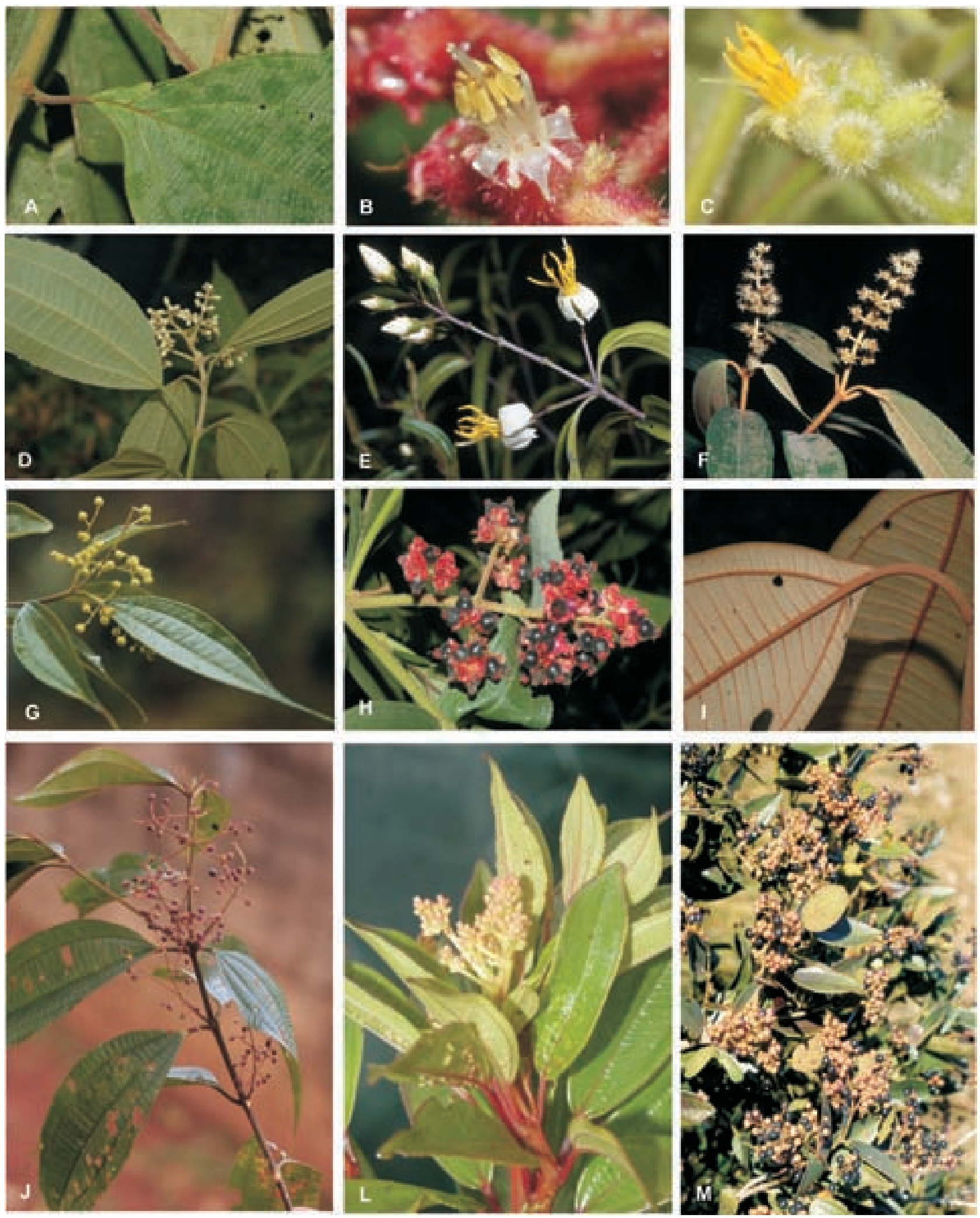

Figura 5. A. Leandra regnellii. Base da lâmina foliar. B: Leandra regnellii. Flor. C. Leandra xanthocoma. Flor. D. Miconia inconspicua. Ramo e inflorescência. E. Miconia langsdorffii. Inflorescência. F. Miconia pepericarpa. Ramo e inflorescência. G. Miconia pusilliflora. Ramo. H. Leandra melastomoides. Inflorescência. I. Miconia chartacea. Base da lâmina (face abaxial). J. Miconia latecrenata. Ramo. L. Miconia theaezans. Ramo. M. Miconia ligustroides. Ramo. (Fotos: A, B, C, D, I e L: F. Michelangeli; E, F, G, H e J: R. Goldenberg; M: A.B. Martins). 
setulosa; 1-2 pares de nervuras acródromas suprabasais. Inflorescências tirsóideas, glomeruladas. Brácteas 5-5,5 × 3,5-6,5 mm, elípticas. Flores (5-)6-meras. Hipanto 4-5 × 2,5-3 mm, tubuloso ou campanulado, densamente revestido por tricomas híspidos, adpressos. Lacínias do cálice: as externas $1,3 \times 0,3 \mathrm{~mm}$, as internas $1,2 \times 0,3 \mathrm{~mm}$. Pétalas 3,5-5 $\times$ 1-1,5 mm, brancas, linear-subuladas. Estames com filetes 3,8-5,5 mm compr.; conectivo não prolongado, inapendiculado; anteras 2,5-4,5 ×0,6-1 mm, subuladas. Ovário adnato até quase a metade ao hipanto, piloso, 4-locular.

Material selecionado: BRASIL. Minas Gerais: Poços de Caldas, 31-I-1919, F.C. Hoehne (SP2706).

Leandra melastomoides é amplamente distribuída no Brasil, ocorrendo nos Estados da Paraíba, Bahia, Goiás, Minas Gerais, Espírito do Santo, Rio de Janeiro, São Paulo, Paraná e Santa Catarina, ocupando matas de restinga, cerrados e matas, em margem de rios, encostas de matas, bordas de trilhas, locais sombreados, úmidos ou secos. No município de Poços de Caldas foi coletada em matas, em locais sombreados.

\subsection{Leandra polystachya (Naudin) Cogn., in} Mart., Fl. Bras. 14(4): 132. 1886. Clidemia polystachya Naudin, Ann. Sci. Nat. Bot. Ser. 3, 17(5): 347. 1851.

Figura 6J-M

Subarbustos 0,5-1 $\mathrm{m}$ alt. Caule, ramos e hipanto com esparsos tricomas hirtelos e furfuráceoestrelados. Folhas com pecíolo 0,3-0,7 cm compr.; lâmina 4,5-8,5 × 2-5 cm, oblonga, base cordada, ápice agudo, margem crenulado-ciliada; face adaxial esparso-estrigosa, com tricomas setulosos esparsos, face abaxial vilosa, furfuráceo-estrelada; 2-3 pares de nervuras acródromas basais. Inflorescências tirsóideas, glomeruladas. Brácteas 2-5 × 1,3 mm, ovais. Flores 5-meras. Hipanto $4 \times 2,5 \mathrm{~mm}$, campanulado. Lacínias do cálice: as externas $2 \times 0,7 \mathrm{~mm}$, as internas $1 \times 0,5 \mathrm{~mm}$. Pétalas 4-5 × 1-1,5 mm, róseas, lanceolado-acuminadas. Estames com filetes 2-3 mm compr.; conectivo não prolongado, inapendiculado; anteras 1-1,5 × $1 \mathrm{~mm}$, subuladas. Ovário adnato até o segundo terço superior ao hipanto, setuloso no ápice, 3-locular.

Material selecionado: BRASIL. Minas GeraIs: Poços de Caldas, Campo de Santa Rosália, 6-XI-1980, G.J. Shepherd 405 (UEC).
Leandra polystachya distribui-se principalmente na Região Sudeste, nos Estados de Minas Gerais, Rio de Janeiro e São Paulo, e também no Paraná e Santa Catarina, sendo encontrada em locais secos e úmidos, em campos de altitude. No município de Poços de Caldas ocorre em campo sujo, em áreas úmidas.

11.11. Leandra purpurascens (DC.) Cogn., in Mart., Fl. Bras. 14 (4): 110.1886. Clidemia purpurascens DC. in DC., Prodr. 3: 161. 1828.

Arbustos 1-4 m alt. Caule, ramos e hipanto com tricomas hirtelos e furfuráceo-estrelados esparsos. Folhas com pecíolo 0,8-1,8 cm compr.; lâmina 5,5-13 × 1,5-4,5 cm, elíptica, base aguda, ápice agudoacuminado, margem crenulada; face adaxial estrigosa, face abaxial vilosa, com tricomas estrelados esparsos; 1-2 pares de nervuras acródromas suprabasais. Inflorescências tirsóideas, fasciculadas. Brácteas 1,2 $\times 0,3 \mathrm{~mm}$, ovais. Flores 5-meras. Hipanto 3-4 $\times$ 2,5-3 mm, tubuloso ou campanulado. Lacínias do cálice: as externas $3,5 \times 3 \mathrm{~mm}$, as internas $1,5 \times 0,5 \mathrm{~mm}$. Pétalas 3,5 × 2,5 mm, brancas, linear-lanceoladas. Estames com filetes 3-4,5 mm compr.; conectivo não prolongado, apêndice inconspícuo; anteras 2-4,5 × 0,5-0,7 mm, subuladas. Ovário adnato até a metade ao hipanto, levemente setuloso no ápice, 3-locular.

Material selecionado: BRASIL. MinAS GERAIS: Poços de Caldas, Fonte dos Amores, 11-XII-1984, I.B. Baldassari et al. 125(UEC).

Leandra purpurascens tem aparentemente uma distribuição disjunta entre a Região Nordeste (Piauí, Paraíba) e as regiões Sudeste e Sul (Minas Gerais, Rio de Janeiro, São Paulo, Paraná, Santa Catarina e Rio Grande do Sul), Ocupa principalmente encostas e bordas de matas ciliares. No município de Poços de Caldas ocorre em matas, em locais sombreados.

12.12. Leandra regnellii (Triana) Cogn., in Mart., Fl. Bras. 14(4):116. 1886. Oxymeris regnellii Triana, Trans. Linn. Soc. London 28(1): 91.1871 [1872].

Figuras 1A-B, 6G-I

Subarbustos a arbustos 0,5-4 m alt. Caule, ramos e hipanto revestidos por esparsos tricomas hirtelos e furfuráceo-estrelados. Folhas com pecíolo 1,5-4,5 cm compr.; lâmina 8-25 × 4,5-15 cm, oval, base arredondada, ápice longo-acuminado, margem levemente serreado-ciliada; ambas as faces esparsamente setulosas, densamente pilosa ao longo 
das nervuras; 3 pares de nervuras acródromas suprabasais. Inflorescências tirsóideas, subfasciculadas. Brácteas $1,2 \times 0,5 \mathrm{~mm}$, subuladas. Flores 5-meras. Hipanto $4 \times 2,5-3 \mathrm{~mm}$, tubuloso. Lacínias do cálice: as externas $1,8 \times 0,4 \mathrm{~mm}$, as internas $0,6 \times$ $0,3 \mathrm{~mm}$. Pétalas $2,5 \times 0,8 \mathrm{~mm}$, brancas, lanceoladosubuladas. Estames com filetes 1,5-2,5 mm compr.; conectivo não prolongado, apêndices inconspícuos; anteras 2,5 ×0,5 mm, oblongas. Ovário adnato além da metade ao hipanto, esparsamente setuloso no ápice, 3(-5)-locular.

Material selecionado: BRASIL. Minas Gerais: Poços de Caldas: XII-1854, Lund 322 (S).

Leandra regnellii ocorre desde o Estado de Minas Gerais até o Rio Grande do Sul, estendendo-se também à Argentina. Indivíduos desta espécie ocupam preferencialmente campos e matas, crescendo em beira de estradas e locais sombreados. No município de Poços de Caldas ocorre em matas.

\subsection{Leandra rigida Cogn., in Mart., Fl. Bras. 14} (4): 134.1886.

Subarbustos até $1 \mathrm{~m}$ alt. Caule, ramos, folhas e hipanto com tricomas dendríticos, ásperos. Folhas com pecíolo 1,5-4,5 cm compr.; lâmina 4,5-8,5 × 3-5 cm, oval, base arredondada a cordada, ápice obtuso; margem levemente serreada; 3-4 pares de nervuras acródromas basais. Inflorescências tirsóideas, fasciculadas. Brácteas $4,5 \times 2,5 \mathrm{~mm}$, ovais. Flores 5-meras. Hipanto 3-3,5 $\times 2,5 \mathrm{~mm}$, oblongocampanulado. Lacínias do cálice: as externas $3,5 \times$ $0,6 \mathrm{~mm}$, as internas $2 \times 0,3 \mathrm{~mm}$. Pétalas $4 \times 2,5 \mathrm{~mm}$, brancas, linear-lanceoladas, acuminadas. Estames com filetes 3-3,5 mm compr.; conectivo não prolongado, espessado no dorso, inapendiculado; anteras 2,5-3 $\times$ 0,5-0,7 mm, subuladas. Ovário adnato até a metade ao hipanto, setuloso no ápice, 3-locular.

Material selecionado: BRASIL. Minas Gerais: Poços de Caldas, 26-VIII-1980, J.Y. Tamashiro et al. 155 (UEC).

Leandra rigida tem distribuição restrita aos Estados de Minas Gerais e Rio de Janeiro, sendo encontrada em campos e cerrados. No município de Poços de Caldas ocorre em campo sujo.

11.14. Leandra sericea DC., in DC., Prodr. 3: 154. 1828.

Arbustos 1-3 m alt. Caule e ramos com tricomas hirtelo-vilosos. Folhas com pecíolo 1-4 cm compr.; lâmina 7,5-14,5 × 3-5,5 cm, elíptica ou oval, base aguda, ápice agudo a acuminado, margem denticuladociliada; face adaxial setosa, face abaxial densamente revestida por tricomas hirtelos, principalmente nas nervuras; 2-3 pares de nervuras acródromas suprabasais. Inflorescências tirsóideas, fasciculadas. Brácteas 5-7 × 4-6 mm, ovais. Flores 6-meras. Hipanto 3-4 $\times 2$-2,5 mm, tubuloso, densamente revestido por tricomas seríceos. Lacínias do cálice: as externas $0,4 \times$ $0,1 \mathrm{~mm}$, as internas $0,8 \times 0,5 \mathrm{~mm}$. Pétalas $4-4,5 \times$ 1,5-2 mm, brancas, lanceolado-acuminadas. Estames com filetes 3-3,6 mm compr.; conectivo prolongado $0,4 \mathrm{~mm}$, calcarado no dorso; anteras 2,5-3,5 $\times$ 0,6-1 mm, subuladas. Ovário livre quase até a base do hipanto, seríceo-piloso, 3-locular.

Material selecionado: BRASIL. Minas Gerais: Poços de Caldas, 2-III-1862, Regnell (S s.n.).

Leandra sericea também tem distribuição basicamente restrita à região sudeste, nos Estados de Minas Gerais, São Paulo e Rio de Janeiro, sendo também encontrada no Paraná, onde ocupa matas e locais sombreados. No município de Poços de Caldas ocorre em matas.

11.15. Leandra xanthocoma (Naudin) Cogn., in Mart., Fl. Bras. 14(4): 124. 1886. Clidemia xanthocoma Naudin, Ann. Sci. Nat. Bot. Ser. 3, 17(5): 352. 1852.

Figuras 5C, 6D-F

Subarbustos a arbustos 0,4-1,5 m alt. Caule e ramos com tricomas hirsutos, amarelos, entremeados por esparsos tricomas furfuráceo-estrelados. Folhas com pecíolo 1-3 cm compr.; lâmina 4-9 × 1,5-5,5 cm, oblonga ou ovada, base arredondada, ápice acuminado, margem crenulado-ciliada; face adaxial esparsamente adpresso-setosa, face abaxial vilosa; 1-2 pares de nervuras acródromas suprabasais. Inflorescências tirsóideas, fasciculadas. Brácteas 2,5-8 × 0,5-1 mm, ovais. Flores 5-meras. Hipanto 6,5 × $3 \mathrm{~mm}$, tubuloso, com tricomas hirtelo-vilosos e furfuráceo-estrelados. Lacínias do cálice: as externas $3,2 \times 1,2 \mathrm{~mm}$, as internas $0,6 \times 0,2 \mathrm{~mm}$. Pétalas $3,8 \times$ 1,6 $\mathrm{mm}$, brancas, linear-lanceoladas. Estames com filetes $2 \mathrm{~mm}$ compr.; conectivo não prolongado, inapendiculado; anteras $5 \times 0,8 \mathrm{~mm}$, linear-subuladas. Ovário livre apenas no ápice, glabro, 3-4-locular.

Material selecionado: BRASIL. Minas Gerais: Poços de Caldas, 9-I-1919, F.C. Hoehne (SP2700). 
Leandra xanthocoma distribui-se nos Estados de Minas Gerais, São Paulo, Rio de Janeiro, Paraná e Santa Catarina, ocorrendo também na Argentina e Uruguai. Ocupa matas e locais sombreados. No município de Poços de Caldas foi coletada em matas.

16.16. Leandra xanthostachya Cogn., in Mart., Fl. Bras. 14(4): 93. 1886.

Figura 6A-C

Subarbustos a arbustos 0,5-2,5 m alt. Caule, ramos e hipanto com tricomas hirsutos e furfuráceoestrelados. Folhas com pecíolo 1,5-5 cm compr.; lâmina 5,5-12 × 2-6 cm, ovalada a elíptica, base obtusa, ápice atenuado-acuminado, margem crenulado-ciliada; ambas as faces revestidas por tricomas setulosos, furfuráceo-estrelados; 2-3 pares de nervuras acródromas suprabasais. Inflorescências tirsóideas, fasciculadas. Brácteas 5,5-6,5 × 0,8-1 mm, elípticas. Flores 5-meras. Hipanto 3,5 × 2,5 mm, tubuloso. Lacínias do cálice: as externas $0,8 \times 0,2 \mathrm{~mm}$, as internas $1,5 \times 0,5 \mathrm{~mm}$. Pétalas $3,3 \times 1,5 \mathrm{~mm}$, róseas, triangular-subuladas. Estames com filetes 2,2-2,8 mm compr.; conectivo não prolongado, inapendiculado; anteras 2-2,8 $\times 0,3-0,5 \mathrm{~mm}$, linear-subuladas. Ovário adnato até o segundo terço superior ao hipanto, glabro, 3-4-locular.

Material selecionado: BRASIL. Minas GeraIs: Poços de Caldas, Fazenda Chiqueirão, 3-XII-1981, H.F. Leitão Filho et al. 1589 (UEC).

Leandra xanthostachya ocorre nos Estados de Minas Gerais, Rio de Janeiro e Paraná, onde ocorre preferencialmente em matas. Em Poços de Caldas esta espécie pode ser encontrada em matas e campo sujo.

12. Miconia Ruiz et Pav., Fl. Peruv. Prodr.: 60. 1794.

Árvores, arvoretas ou arbustos. Caule e ramos glabros ou com indumento variável. Folhas opostas ou raro verticiladas, pecioladas ou sésseis, glabras ou pilosas; 3-5-nervuras acródromas basais ou suprabasais, com ou sem domácias. Inflorescências dispostas em panícula e inflorescências parciais dicasiais, glomeruladas, espiciformes ou escorpióides, terminais ou laterais. Brácteas persistentes ou caducas. Flores 5-meras, raro 4, 6 ou 8-meras. Hipanto campanulado a cilíndrico, glabro ou piloso. Cálice simples ou duplo. Lacínias do cálice agudas a subuladas, persistentes ou tardiamente caducas. Pétalas brancas a amareladas, raro rosadas, ovais, obovais ou oblongas, obtusas, raro apiculadas, ápice arredondado, retuso ou obtuso, nunca agudo. Estames geralmente em número duplo ao das pétalas, dimorfos ou isomorfos; filetes geralmente glabros; conectivo simples ou basalmente prolongado, com ou sem apêndice dorsal ou ventral; anteras de forma variável, amarelas, brancas ou roxas, uniporadas, raro 2 ou 4-poradas ou rimosas. Ovário ínfero a semi-ínfero, glabro, (1-)2-5-locular; estigma truncado, capitado, peltado ou discóide, raro obtuso. Fruto baga. Sementes 1 ou várias, piramidais a ovais.

O gênero Miconia apresenta cerca de 1.056 espécies que ocorrem desde o sul do México até o norte da Argentina e Uruguai (Goldenberg 2004), constituindo o maior gênero da família Melastomataceae (Wurdack 1983, Martins et al. 1996). No Brasil, o gênero está representado por cerca de 250 espécies que ocorrem em diversas formações vegetais, florestas, cerrados, campos e campos rupestres. De taxonomia difícil, Miconia distingue-se dos demais gêneros pertencentes à tribo Miconieae principalmente por apresentar inflorescências terminais e ápice das pétalas arredondado, retuso ou obtuso, nunca agudo. No município de Poços de Caldas foram encontradas 17 espécies de Miconia.

Chave para as espécies de Miconia de Poços de Caldas

1. Folhas com nervuras acródromas suprabasais

2. Caule, ramos, folhas e hipanto totalmente glabros 12.2. M. chamissois

2. Caule, ramos, folhas e hipanto com indumento variável

3. Face abaxial da folha furfurácea nas nervuras 12.9. M. langsdorffii

3. Face abaxial da folha inteiramente revestida por tricomas estrelados a estrelado-tomentosos, canescentes a ferrugíneos

4. Hipanto revestido por tricomas estrelados, furfuráceos, entremeados por esparsos tricomas dendríticos. 12.13. M. pepericarpa

4. Hipanto com tricomas variados, nunca entremeados por tricomas dendríticos 
5. Pétalas rosadas

12.17. M. tristis

5. Pétalas brancas

6. Cálice persistente; lacínias externas formando dentículos agudos

12.1. M. chartacea

6. Cálice caduco; lacínias externas subuladas, agudas ou reduzidas a dentículos triangulares, diminutos ou inconspícuos

7. Folha com base longo-atenuada, decurrente no pecíolo

12.7. M. discolor

7. Folha com base aguda, abruptamente atenuada, obtusa a arredondada, nunca decurrente no pecíolo

8. Base da lâmina com domácias 12.15. M. sellowiana

8. Base da lâmina sem domácias

9. Folhas com projeções interpeciolares nos nós; lâmina foliar elíptica a oval-lanceolada 12.4. M. cinnamomifolia

9. Folhas sem projeções interpeciolares nos nós; lâmina foliar oval a amplamente oval 12.5. M. corallina

1. Folhas com nervuras acródromas basais

10. Planta totalmente glabra; anteras 4-poradas 12.16. M. theaezans

10. Planta com indumento variável; anteras 1-2-poradas ou com deiscência longitudinal ampla

11. Anteras 2-poradas

12. Folhas com ápice acuminado, margem denticulada ou denteada; hipanto glabro

12.8. M. inconspicua

12. Folhas com ápice atenuado, acuminado, margem inteira a repanda; hipanto com tricomas ferrugíneo-estrelados, furfuráceos 12.6. M. cyathanthera

11. Anteras uniporadas ou com deiscência longitudinal ampla

13. Folha com base atenuada, ápice longo-caudado; conectivo inapendiculado; anteras com deiscência longitudinal ampla 12.14. M. pusilliflora

13. Folhas com base arredondada, ápice agudo a acuminado; conectivo com apêndice basal amplo e dois apêndices ventrais; anteras com deiscência poricida

14. Lâmina foliar elíptico-lanceolada a lanceolada; filetes $2 \mathrm{~mm}$ compr.

12.10. M. latecrenata

14. Lâmina foliar elíptica; filetes $4 \mathrm{~mm}$ compr.

15. Folha com margem denteada; ovário com esparsos tricomas no ápice

12.3. M. cinerascens

15. Folha com margem inteira, ondulada ou repanda; ovário totalmente glabro

16. Lâmina com ambas as faces glabras a glabrescentes 12.11. M. ligustroides

16. Lâmina com face abaxial face adaxial pruinosa e face adaxial densamente revestida por tricomas cinzentos a canescente-estrelados 12.12. M. paulensis

12.1. Miconia chartacea Triana, Trans. Linn. Soc. London 28: 119. 1871.

Figuras 5I, 7G-I

Arvoretas 4,5-5 m alt. Caule, ramos, face abaxial das folhas e hipanto densamente revestidos por tricomas furfuráceo-estrelados, face adaxial das folhas glabrescentes. Folhas com pecíolo 1-2,8 cm compr.; lâmina 7,5-16,5 × 2-4,5 cm, lanceolada a linearlanceolada, base aguda, ápice agudo a acuminado, margem ondulada; 1 -3 pares de nervuras acródromas suprabasais; domácias ausentes. Panículas de glomérulos, terminais e laterais. Flores 5-meras. Hipanto 2,5-3 × 2-2,5 mm, campanulado. Cálice persistente; lacínias internas $0,6 \times 0,4 \mathrm{~mm}$, triangulares, as externas formando dentículos agudos. Pétalas $2 \times$ $1 \mathrm{~mm}$, brancas, obovais. Estames com filetes ca. $4 \mathrm{~mm}$ compr.; conectivo com dois apêndices dorsais curtos; anteras $2 \times 0,4 \mathrm{~mm}$, oblongas, ápice truncado, uniporadas. Ovário adnato até o segundo terço superior ao hipanto, glabro, 2-3-locular.

Material selecionado: BRASIL. Minas Gerais: Poços de Caldas, 5-V-1874, Mosen 1847 (S).

Miconia chartacea ocorre na Bahia, Distrito Federal, Minas Gerais, São Paulo, Rio de Janeiro até Santa Catarina. Ocupa formações florestais e 

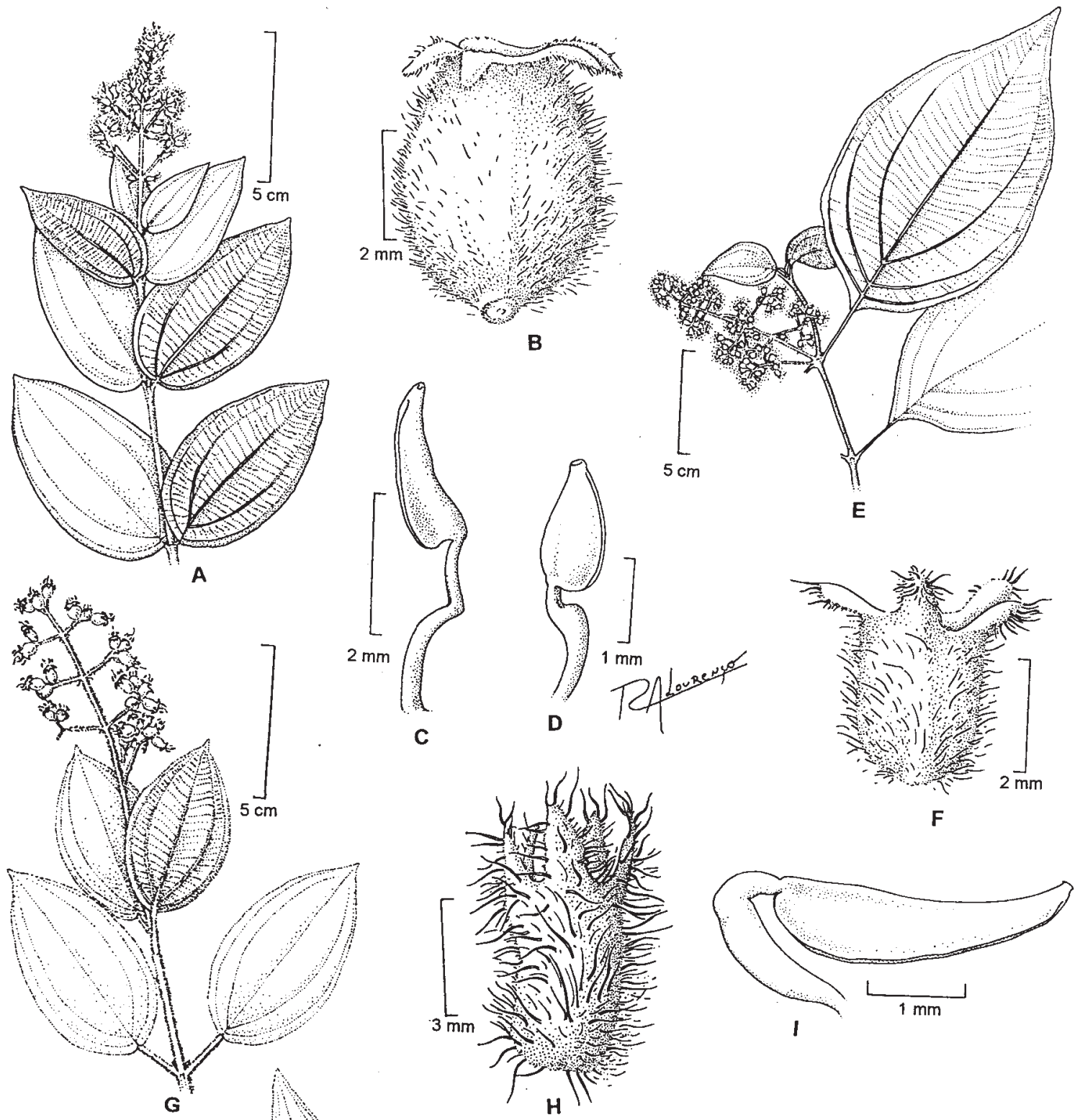

$\mathrm{H}$
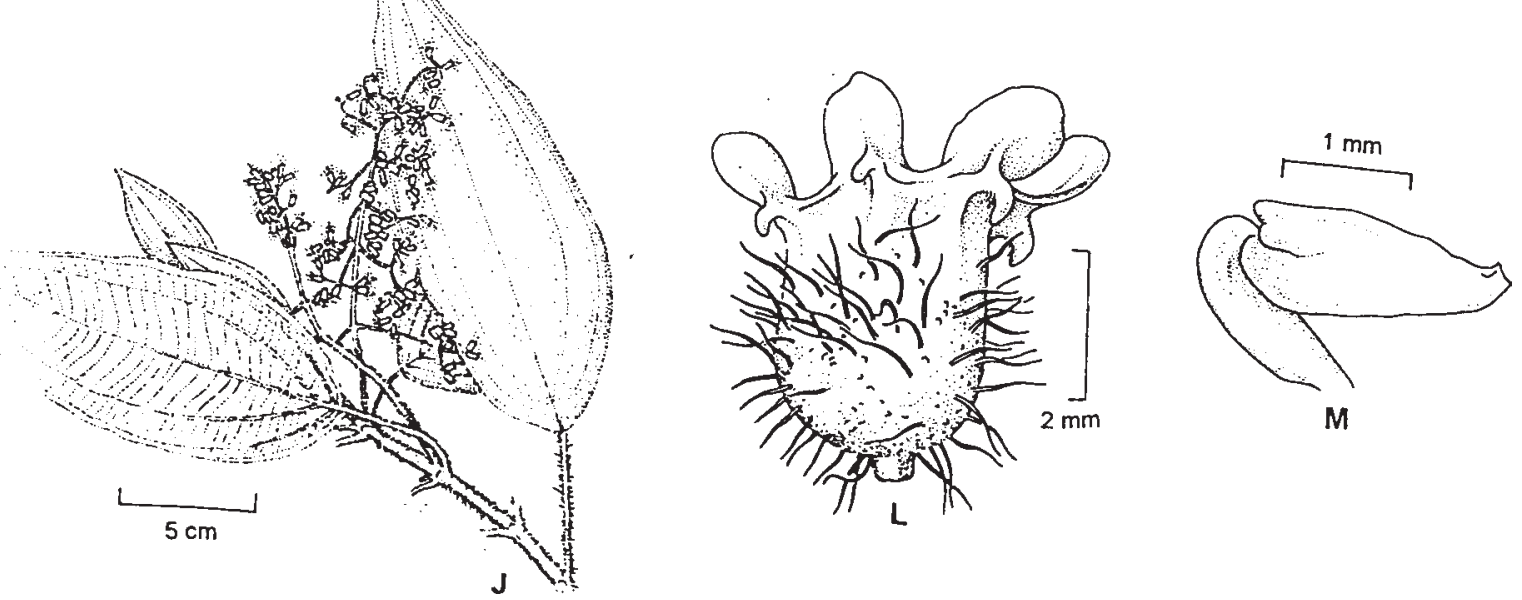

Figura 6. A-C. Leandra xanthostachya. A. Ramo. B. Hipanto. C. Estame. (H.F. Leitão Filho et al. 1589 (UEC)). D-F. Leandra xanthocoma. D. Ramo. E. Hipanto. F. Estame. (G.J. Shepherd et al. s.n. (UEC6898)). G-I. Leandra regnellii. G. Ramo. H. Hipanto. I. Estame. (M.G. Papp \& C. Oishi 12 (UEC)). J-M. Leandra polystachya. J. Ramo. L. Hipanto. M. Estame. (R. Silva P14 (UEC)). 
cerrados (Martins et al. 1996, Goldenberg 2004). No município de Poços de Caldas foi coletada em campo sujo e em bordas de matas.

\subsection{Miconia chamissois Naudin, Ann. Sci. Nat. Bot.}

Ser. 3, 16: 179. 1851.

Arbustos 1,5-2 m alt. Caule, ramos, folhas e hipanto totalmente glabros. Folhas com pecíolo 0,5-2 cm compr.; lâmina 8,5-18,5 ×3,5-10,5 cm, elíptica a amplamente oval ou oboval, base abruptamente atenuada, ápice agudo, acuminado, margem inteira a ondulada; 2-3 pares de nervuras acródromas suprabasais; domácias ausentes. Panículas terminais. Flores 5-meras. Hipanto 2,5-3 × 1,7-2 mm, campanulado. Cálice persistente; lacínias internas $0,4 \times 0,2 \mathrm{~mm}$ compr., triangulares, as externas reduzidas a dentículos muito reduzidos. Pétalas 2-3× 1-1,5 mm, brancas, obovais. Estames com filetes $3 \mathrm{~mm}$ compr.; conectivo com apêndice basal amplo nos estames ante-sépalos e com cálcar dorsal e aurículas ventrais nos antepétalos; anteras $2,3 \times 0,5 \mathrm{~mm}$, oblongas, levemente atenuada em direção ao ápice, uniporadas. Ovário adnato até a metade ao hipanto, esparsos tricomas glandulares curtos, 3-5-locular.

Material selecionado: BRASIL. Minas Gerais: Poços de Caldas, 29-I-1864, Regnell II/34 (S).

No Brasil Miconia chamissois ocorre nos Estados do Ceará, Piauí, Paraíba, Mato Grosso, Goiás, Distrito Federal, Minas Gerais, Rio de Janeiro, São Paulo e Paraná, onde ocupa locais alagados em matas e cerrados. Esta espécie também pode ser encontrada na Guiana Francesa e Bolívia (Goldenberg 2004). No município de Poços de Caldas cresce em matas, locais úmidos, brejos e campos.

\subsection{Miconia cinerascens Miq. var. cinerascens,} Linnaea 22: 543. 1849.

Arbustos a árvores 1-6,5 m alt. Caule e ramos com tricomas estrelados ou dendríticos curtos. Folhas com pecíolo 0,8-3,8 cm compr.; lâmina 7-16 × 2-7,5 cm, elíptica a elíptico-lanceolada a oblongolanceolada, base arredondada, ápice agudo a acuminado, margem denteada, face adaxial glabra, face abaxial densamente revestida por tricomas cinéreo-estrelados; 2-3 pares de nervuras acródromas basais; domácias ausentes. Panículas de glomérulos. Flores 5 ou 6-meras. Hipanto 2,5 × 1,2 mm, campanulado, densamente revestido por tricomas cinéreo-estrelados. Cálice caduco; lacínias internas
$1 \times 0,5 \mathrm{~mm}$, repandas, as externas reduzidas a dentículos. Pétalas 2-2,5 × 1,8 mm, brancas, obovais. Estames com filetes $5 \mathrm{~mm}$ compr.; conectivo com um apêndice dorsal e duas projeções ventrais diminutas; anteras 2-2,5 $\times 0,5 \mathrm{~mm}$, lineares, ápice truncado, uniporadas. Ovário adnato até o segundo terço superior ao hipanto, glabro ou tricomas esparsos no ápice, 3-locular.

Material selecionado: BRASIL. Minas GeraIs: Poços de Caldas, Campo de Santa Rosália, 6-XI-1980, A.C. Gabrielli et al. 400 (UEC).

Miconia cinerascens ocorre desde Minas Gerais até o Rio Grande do Sul, Paraguai e norte da Argentina, onde ocupa campos, matas, locais úmidos e sombreados (Martins et al. 1996, Goldenberg 2004). No município de Poços de Caldas foi coletada em matas, em áreas úmidas.

12.4. Miconia cinnamomifolia (DC.) Naudin, Ann. Sci. Nat. Bot. Ser. 3, 16: 168. 1851. Cremanium cinnamomifolium DC., Prodr. 3: 194. 1828.

Árvores 3-15 m alt., raro arbustos 1,5 m alt. Caule, ramos, folhas e hipanto com esparsos tricomas estrelados. Folhas com pecíolo 1-2 cm compr., projeções interpeciolares nos nós; lâmina 5,5-12,5 × 1,5-5,5 mm, elíptica a oval-lanceolada, base aguda, ápice agudo a acuminado, margem ondulada,; 2-3 pares de nervuras acródromas suprabasais; domácias ausentes. Panículas terminais. Flores (4-)5-meras. Hipanto 1,5-2 × 1,4 mm, campanulado. Cálice caduco; lacínias internas $0,5 \times 0,3 \mathrm{~mm}$, arredondadas, as externas reduzidas a dentículos triangulares. Pétalas 1,5-2 $\times 1-1,5 \mathrm{~mm}$, brancas, ovais. Estames com filetes $4 \mathrm{~mm}$ compr.; conectivo com apêndice basal amplo, ou com um calcar dorsal alargado e duas aurículas ventrais; anteras $2 \times 0,3 \mathrm{~mm}$, lineares, ápice truncado, uniporadas. Ovário adnato até a metade ao hipanto, glabro, 3-locular.

Material selecionado: BRASIL. Minas Gerais: Poços de Caldas, estrada Andradas-Poços de Caldas, Serra do Caracol, 7-I-1981, H.F. Leitão Filho et al. 1452 (UEC).

Miconia cinnamomifolia é encontrada desde a Bahia até Santa Catarina (Martins et al. 1996, Goldenberg 2004). Ocupa matas e formações costeiras. No município de Poços de Caldas pode ser encontrada em bordas de matas, próxima a cursos d'água. 
12.5. Miconia corallina Spring. Flora 20. Beibl. 2: 77. 1837.

Figura 7J-M

Arbustos 1-3 m alt. Caule, ramos, hipanto e face abaxial das folhas revestidos por tricomas estreladotomentosos, canescentes a ferrugíneos. Folhas com pecíolo 2-3 cm compr.; lâmina 8,5-12,5 × 5-9,5 cm, oval a amplamente oval, base arredondada a subcordada, ápice obtuso, margem inteira a subdenticulada, face adaxial curtamente estreladotomentosa, depois glabra; 1-2 pares de nervuras acródromas suprabasais; domácias ausentes. Panículas espiciformes de glomérulos, terminais. Flores 4-meras. Hipanto 2-2,5 × 1,5-2 mm, campanulado. Cálice caduco; lacínias internas $0,3 \times$ $0,2 \mathrm{~mm}$, repandas a arredondadas, as externas reduzidas a dentículos triangulares. Pétalas 1,5-2,2 $\times$ $1 \mathrm{~mm}$, brancas, obovais. Estames com filetes $5 \mathrm{~mm}$ compr.; conectivo inapendiculado; anteras $1 \times 0,5 \mathrm{~mm}$, atenuadas na base e alargadas no ápice, uniporadas. Ovário adnato até a metade ao hipanto, glabro, 1-3-locular.

Material selecionado: BRASIL. MinAs GERAIs: Poços de Caldas, 27-XII-1862, Regnell III-34-c (S).

Miconia corallina ocorre nos Estados de Minas Gerais, São Paulo e Rio de Janeiro. Ocupa cerrados, campos e campos de altitude (Martins et al. 1996). No município de Poços de Caldas foi coletada em mata.

12.6. Miconia cyathanthera Triana, Trans. Linn. Soc. London 28 (1): 137. 1871.

Figura 7D-F

Subarbustos a arbustos 0,5-1 $\mathrm{m}$ alt. Caule, ramos, folhas e hipanto ferrugíneo-estrelados, furfuráceos. Folhas com pecíolo 2-6 mm compr.; lâmina 2-5,5 $\times$ 0,2-1 cm, linear a linear-lanceolada, base aguda, ápice atenuado, acuminado, margem inteira a repanda; 1-2 pares de nervuras acródromas basais; domácias ausentes. Panículas terminais. Flores 5-meras. Hipanto 1,5 × 1,7 mm, campanulado. Cálice persistente; lacínias internas $0,6 \times 0,3 \mathrm{~mm}$, triangulares, as externas reduzidas a dentículos triangulares. Pétalas $1,5 \times$ $0,7 \mathrm{~mm}$, brancas, obovais. Estames com filetes $6 \mathrm{~mm}$ compr.; conectivo inapendiculado; anteras 0,7-1 $\times$ 0,3 mm, oblongas, ápice truncado, 2-poradas. Ovário adnato até a metade ao hipanto, glabro, 3-locular.

Material selecionado: BRASIL. MinAs GeRAIS: Poços de Caldas, 5-X-1873, Mosen 487 (S).
Miconia cyathanthera ocorre nos Estados de Bahia, Minas Gerais e Distrito Federal, preferencialmente em campos. No município de Poços de Caldas foi encontrada em campo sujo.

12.7. Miconia discolor DC. in DC., Prodr. 3: 184. 1828.

Figura 1J

Arbustos a arvoretas 1-5 m alt. Caule, ramos, hipanto e face abaxial das folhas densamente revestidos por indumento adpresso-estrelado, canescente. Folhas com pecíolo 0,5-2,5 cm compr.; lâmina 9-26×2,5-10 cm, oblanceolada a obovada, base longo-atenuada, decurrente no pecíolo, ápice obtuso a curtamente acuminado, margem crenulada, face adaxial glabra; 1-2 pares de nervuras acródromas suprabasais; domácias ausentes. Panículas de glomérulos terminais. Flores 5-meras. Hipanto 2,5 $\times$ 2,2 mm, campanulado. Cálice caduco; lacínias internas $0,5 \times 0,2 \mathrm{~mm}$, triangulares, as externas reduzidas a dentículos inconspícuos. Pétalas 2,5 × 1,6 mm, brancas, obovais. Estames com filetes $3 \mathrm{~mm}$ compr.; conectivo com apêndice provido de duas aurículas ventrais; anteras 2,5 $\times 0,4 \mathrm{~mm}$, oblongas, levemente atenuadas no ápice, uniporadas. Ovário adnato até o segundo terço superior ao hipanto, glabro, 3-locular.

Material selecionado: BRASIL. Minas Gerais: Poços de Caldas, Mata da Colina, XII-1984, F.R. Martins 248 (UEC).

Miconia discolor ocorre desde Minas Gerais, São Paulo, Rio de Janeiro, Paraná e Santa Catarina até o Paraguai e norte da Argentina. Ocupa matas, matas de galeria, locais sombreados, próximo a rochas calcáreas (Martins et al. 1996, Goldenberg 2004). No município de Poços de Caldas é encontrada em borda de matas.

12.8. Miconia inconspicua Miq., Linnaea 22: 542. 1849.

Figura 5D

Árvores ou arvoretas 4-6 m alt. Caule, ramos, face abaxial das folhas e hipanto revestidos por tricomas estrelados. Folhas com pecíolo 0,8-2,4 cm compr.; lâmina 6-14 × 1,5-4,5 cm, lanceolada a oblongo-lanceolada, base aguda, ápice acuminado, margem denticulada ou denteada, face adaxial glabra ou glabrescente; 1-2 pares de nervuras acródromas basais; domácias ausentes. Panículas terminais. Flores 5-meras. Hipanto 1,8 ×0,7 mm, campanulado, glabro. 
Cálice persistente; lacínias internas $0,8 \times 0,4 \mathrm{~mm}$, triangulares, as externas formando dentículos triangulares, inconspícuos. Pétalas 1,8 × 1,4 mm, brancas, obovais. Estames com filetes $2,4 \mathrm{~mm}$ compr.; conectivo dorsalmente espessado com apêndice basal amplo, bilobado; anteras $1,2 \times 0,5 \mathrm{~mm}$, obovais, ápice 2-poradas. Ovário adnato até a metade ao hipanto, ápice com tricomas, 3-locular.

Material selecionado: BRASIL. Minas Gerais: Poços de Caldas, 9-IX-1864, Regnell II-110 (R).

Miconia inconspicua ocorre desde Minas Gerais até o Paraná, onde ocupa preferencialmente matas (Goldenberg 2004). No município de Poços de Caldas foi coletada em matas.

12.9. Miconia langsdorffii Cogn., in Mart., Fl. Bras. 14(4): 232. 1887.

\section{Figura 5E}

Arbustos 0,8-1m alt. Caule, ramos e hipanto revestidos por tricomas estrelados esparsos, posteriormente glabros. Folhas com pecíolo $0,5 \mathrm{~cm}$ compr.; lâmina 2,5-6 × 0,7-1,5 cm, lanceolada, base obtusa a arredondada, ápice agudo, acuminado, margem serrilhada, face adaxial glabra, face abaxial furfurácea nas nervuras; 1-2 pares de nervuras acródromas suprabasais; domácias ausentes. Panícula de racemos terminais. Flores 5-meras. Hipanto 2,5-3 $\times$ 1,7-2 mm, campanulado, glabro. Cálice caduco; lacínias internas $0,6 \times 0,2 \mathrm{~mm}$, as externas $1 \times 0,8 \mathrm{~mm}$, ambas subuladas. Pétalas $6,5 \times 3,5 \mathrm{~mm}$, brancas, obovais. Estames com filetes $1,5 \mathrm{~mm}$ compr.; conectivo espessado dorsalmente, provido de tricomas glandulares na base; dois apêndices ventrais; anteras 3,5-4,5 × 0,5-0,8 mm, subuladas, falciformes, uniporadas. Ovário livre até o segundo terço inferior, glabro, 3-locular.

Material selecionado: BRASIL. MinAs GeraIs: Poços de Caldas, 1-XII-1870, Regnell I-144 (S).

Miconia langsdorffii ocorre desde de Minas Gerais até o Paraná e Paraguai (Goldenberg 2004). Ocupa preferencialmente campos e locais sombreados (Martins et al. 1996, Goldenberg 2004). No município de Poços de Caldas foi coletada em campo sujo.

12.10. Miconia latecrenata (DC.) Naudin, Ann. Sci.

Nat. Bot. Ser. 3, 16: 239. 1851. Cremarium latecrenatum DC. in DC., Prodr., 3: 194.1828.

Figura 5J
Arbustos a arvoretas 2,5-4,5 m alt. Caule, ramos, face abaxial das folhas e hipanto com esparsos tricomas estrelados. Folhas com pecíolo 0,4-1,5 cm compr.; lâmina 6,5-17 ×2-3,5 cm, elíptico-lanceolada a lanceolada, base arredondada, ápice longoacuminado, margem repanda, face adaxial com esparsos tricomas hirsutos; 2-3 pares de nervuras acródromas basais; domácias ausentes. Panículas terminais e laterais. Flores 5-meras. Hipanto 1,8 $\times$ $1 \mathrm{~mm}$, campanulado. Cálice caduco; lacínias internas $0,4 \times 0,2 \mathrm{~mm}$, amplamente triangulares, as externas reduzidas a dentículos. Pétalas $1,8 \times 0,8 \mathrm{~mm}$, brancas, obovais. Estames com filetes $2 \mathrm{~mm}$ compr.; conectivo basalmente espessado, apêndice dorsal e dois ventrais; anteras 1-1,3 × 0,4 mm, lineares, ápice truncado, uniporadas. Ovário adnato até a metade ao hipanto, ápice esparsamente estrelado, 3-locular.

Material selecionado: BRASIL. MinAs GeraIs: Poços de Caldas, Mata da Colina, 1-X-1980, H.F. Leitão Filho et al. 67 (UEC).

Miconia latecrenata é amplamente distribuída desde o Piauí até o Rio Grande do Sul, onde ocupa matas e formações costeiras (Martins et al. 1996, Goldenberg 2004). Em Poços de Caldas foi coletada em matas.

12.11. Miconia ligustroides (DC.) Naudin, Ann. Sci. Nat. Bot. Ser. 3, 16: 167. 1851. Cremanium ligustroides DC. in DC., Prodr. 3: 194. 1828. Figura 5M, 7A-C

Arbustos a árvores 0,5-4,5 m alt. Caule, ramos e hipanto com diminutos tricomas estrelados, posteriormente glabrescentes. Folhas com pecíolo 0,5 cm compr.; lâmina 3-9 × 1,5-4 cm, elíptica, base arredondada, ápice agudo a acuminado, margem inteira ou repanda, ambas as faces glabras ou glabrescentes; 1-2 pares de nervuras acródromas basais; domácias ausentes. Panículas terminais. Flores 5-meras. Hipanto 1,8 $\times 2 \mathrm{~mm}$, campanulado. Cálice caduco; lacínias internas $0,6 \times 0,3 \mathrm{~mm}$, arredondadas, as externas reduzidas a dentículos triangulares. Pétalas 2,5 $\times 1,2 \mathrm{~mm}$, brancas, obovais. Estames com filetes 2,5-3,5 mm compr.; conectivo com apêndice basal amplo e dois apêndices ventrais; anteras 3-3,2 × $0,4 \mathrm{~mm}$, lineares, mais estreitas na base, ápice truncado, uniporadas. Ovário adnato até a metade ao hipanto, glabro, 3-locular.

Material selecionado: BRASIL. Minas Gerais: Poços 
de Caldas, Campo do Saco, 13-I-1981, L.S. Kinoshita et al. 721 (UEC).

Miconia ligustroides é amplamente distribuída, ocorrendo desde o Ceará até Santa Catarina. Ocupa geralmente cerrados, campos, locais úmidos e brejos (Martins et al. 1996, Goldenberg 2004). No município de Poços de Caldas ocorre em campo sujo.

12.12. Miconia paulensis Naudin, Ann. Sci. Nat. Bot. Ser. 3, 16: 187. 1851.

Arbustos ou arvoretas 1-4 m alt. Caule, ramos, face abaxial das folhas e hipanto revestidos por
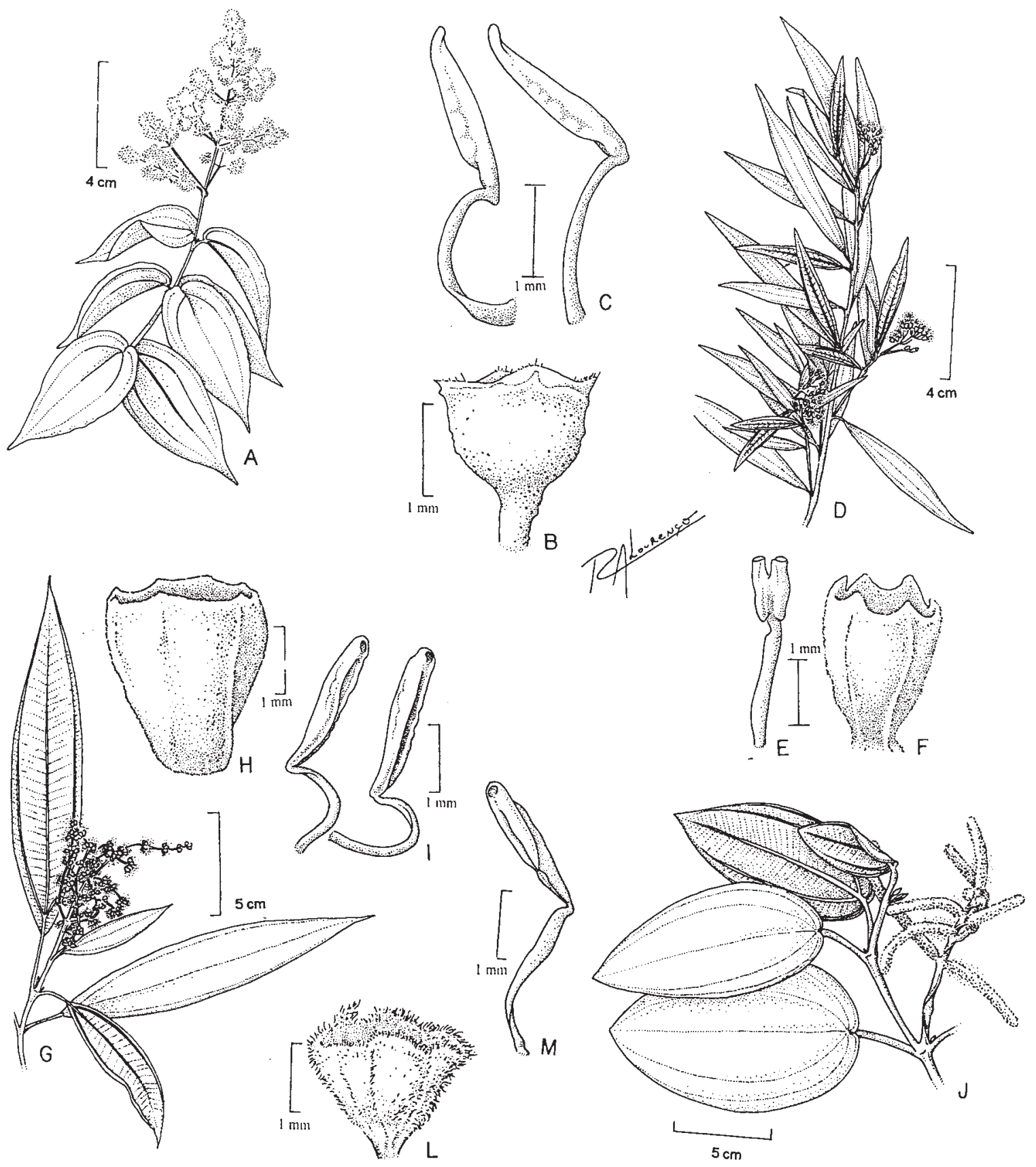

Figura 7. A-C. Miconia ligustroides. A. Ramo. B. Hipanto. C. Estames. (F.R. Martins et al. 208 (UEC)). D-F. Miconia cyathanthera. D. Ramo. E. Estame com antera 2-porada. F. Hipanto. (H.F. Leitão Filho et al. 15323 (UEC)). G-I. Miconia chartacea. G. Ramo. H. Hipanto. I. Estames. (R. Romero et al. 3177 (UEC)). J-M. Miconia corallina. J. Ramo. L. Hipanto. M. Estame. (R. Goldenberg \& G.J. Shepherd 127 (UEC)). 
tricomas estrelados cinéreos a canescente, posteriormente glabrescentes. Folhas com pecíolo 0,5-0,8 cm compr.; lâmina 7-12 × 1,5-3,5 cm, oblongolanceolada, base arredondada, ápice agudo a curtamente acuminado, margem inteira a ondulada, face adaxial pruinosa, posteriormente glabra; 1-2 pares de nervuras acródromas basais; domácias ausentes. Panículas terminais. Flores 5-meras. Hipanto 2-2,5 × 1-1,5 mm, campanulado. Cálice caduco; lacínias internas $0,5 \times 0,3 \mathrm{~mm}$, arredondadas, as externas reduzidas a dentículos triangulares. Pétalas 2-2,5 × 1,5-2 mm, brancas, obovais. Estames com filetes $3 \mathrm{~mm}$ compr.; conectivo espessado, posteriormente calcarado na base; inapendiculado; anteras 2-2,5 × 0,5-0,7 mm, lineares, ápice truncado, uniporadas. Ovário adnato até o segundo terço superior ao hipanto, glabro, 3-locular.

Material selecionado: BRASIL. Minas Gerais: Poços de Caldas, Campo do Saco, 28-X-1981, J.Y. Tamashiro et al. 1309 (UEC).

Miconia paulensis ocorre nos Estados de Minas Gerais e São Paulo, em campos e matas. No município de Poços de Caldas foi coletada em campo sujo e em bordas de matas.

12.13. Miconia pepericarpa Mart. ex DC., Prodr. 3: 182. 1828.

Figura 5F

Arbustos com até $3 \mathrm{~m}$ alt. Caule, ramos e hipanto revestidos por tricomas estrelados, furfuráceos, entremeados por esparsos tricomas dendríticos. Folhas com pecíolo 0,5-1,5 cm compr.; lâmina 5,5 × 10-12 cm, oblongo-lanceolada, base arredondada, ápice longoacuminado, margem inteira, revoluta, face adaxial furfurácea, glabrescente, face abaxial revestida por tricomas estrelados; $1-2$ pares de nervuras acródromas suprabasais; domácias ausentes. Panículas de glomérulos, terminais e laterais. Flores 4-meras. Hipanto 1,5 × 1-1,2 mm, campanulado. Cálice persistente; lacínias internas $0,5 \times 0,2 \mathrm{~mm}$, amplamente triangulares, as externas agudas, diminutas. Pétalas $1,5 \times 1 \mathrm{~mm}$, brancas, oblongas. Estames com filetes ca. 1,5 mm compr.; conectivo espessado no dorso; inapendiculado; anteras 1,5 ×0,3 mm, oblongo-lineares, ápice truncado, uniporadas. Ovário adnato até a metade ao hipanto, estrigoso no ápice, 2-3-locular.

Material selecionado: BRASIL. Minas Gerais: Poços de Caldas, Rod. Poços de Caldas-Campestre, 1-XII-1982, H.F. Leitão Filho et al. 1456 (UEC).
Miconia pepericarpa ocorre no Distrito Federal e nos Estados de Goiás, Minas Gerais e São Paulo, onde ocupa campos, cerrados e matas (Martins et al. 1996). No município de Poços de Caldas ocorre em campo sujo.

12.14. Miconia pusilliflora (DC.) Naudin, Ann. Sci. Nat. Bot. Ser. 3, 16: 171. 1851. Cremanium pusilliflorum DC. in DC., Prodr. 3: 194. 1828. Figura 2G

Árvores até $6 \mathrm{~m}$ a arbustos com 1,5 $\mathrm{m}$ alt. Caule, ramos, ambas as faces da folha e hipanto revestidos por tricomas estrelado-furfuráceo. Folhas com pecíolo 0,5-1,5 cm compr.; lâmina 4-15 ×2-4,5 cm, elíptica a oblonga, base atenuada, ápice longo-caudado, margem inteira ou serreada; 1 -2 pares de nervuras acródromas basais; domácias ausentes. Panículas terminais. Flores 4-5-meras. Hipanto 1,2-1,5 × 1,2-2 mm, campanulado. Cálice caduco; lacínias internas $0,4 \times 0,2 \mathrm{~mm}$, triangulares, as externas $0,3 \times 0,2 \mathrm{~mm}$, triangulares ou formando dentículos. Pétalas $2 \times 1,3 \mathrm{~mm}$, brancas, oblongas. Estames com filetes $3 \mathrm{~mm}$ compr.; conectivo levemente prolongado, inapendiculado; anteras $1,2 \times 0,5 \mathrm{~mm}$, lineares, com deiscência longitudinal ampla. Ovário adnato até a metade ao hipanto, glabro, 3-locular.

Material selecionado: BRASIL. Minas GeraIs: Poços de Caldas, Mata da Colina, 14-X-1980, F.R. Martins et al. 237 (UEC).

Miconia pusilliflora ocorre desde o Espírito Santo até o Rio Grande do Sul, Argentina e Paraguai, onde ocupa preferencialmente matas, formações costeiras (Goldenberg 2004). No município de Poços de Caldas foi coletada em matas.

12.15. Miconia sellowiana Naudin, Ann. Sci. Nat. Bot. Ser. 3, 16: 206. 1851.

Árvores 8-15 m ou arbustos até $2 \mathrm{~m}$ alt. Caule, ramos, ambas as faces da folha e hipanto esparsamente revestidos por tricomas estreladofurfúraceos, posteriormente glabrescentes. Folhas com pecíolo 0,3-1 cm compr.; lâmina 4,5-12 × 1-3 cm, lanceolada a oblongo-lanceolada, base obtusa, ápice longo-acuminado a caudado, margem levemente serreada; 1-2 pares de nervuras acródromas suprabasais; presença de domácias. Panículas terminais. Flores 5-meras. Hipanto 1,5 $\times 1,3 \mathrm{~mm}$, campanulado. Cálice caduco; lacínias internas $0,3 \times$ $0,2 \mathrm{~mm}$, arredondadas, as externas triangulares. 
Pétalas 1,8 × 1,3 mm, brancas, obovais. Estames com filetes $3 \mathrm{~mm}$ compr.; conectivo com apêndices ventrais diminutos; anteras $1,8 \times 0,4 \mathrm{~mm}$, lineares, com abertura ventral ampla, semelhante a rimas. Ovário adnato somente no terço inferior ao hipanto, glabro, papiloso no ápice, 3-locular.

Material selecionado: BRASIL. Minas GeRAIS: Poços de Caldas, Campo de Santa Rosália, 3-IX-1980, H.F. Leitão Filho et al. 52 (UEC).

Miconia sellowiana ocorre de Goiás até o Rio Grande do Sul, onde pode ser encontrada em matas e cerrados (Goldenberg 2004). No município de Poços de Caldas esta espécie foi coletada em bordas de matas próximas a rios.

12.16. Miconia theaezans (Bonpl.) Cogn., in Mart., Fl. Bras. 14(4): 419. 1888. Melastoma theazans Bonpl. in Humb. \& Bonpl., Monogr. Melast. 1:17. t. 9. 1807.

\section{Figura 5L}

Arbustos 0,5-2 m alt, totalmente glabros. Folhas com pecíolo 1,8-2,4 cm compr.; lâmina 2,5-12,5 × 0,8-4,8 cm, elíptica a oboval, base atenuada a arredondada, ápice acuminado, margem serrilhadociliada; 2-3 pares de nervuras acródromas basais; domácias ausentes. Panículas terminais. Flores 5-meras. Hipanto 1,5 × 0,8 mm, campanulado. Cálice persistente; lacínias internas $0,5 \times 0,2 \mathrm{~mm}$, arredondadas, as externas formando dentículos triangulares. Pétalas 1,5 × 1,4 mm, brancas, obovais. Estames com filetes $2 \mathrm{~mm}$ compr.; conectivo espessado com dois apêndices ventrais curtos; anteras $1 \times 0,4 \mathrm{~mm}$, obovais, ápice truncado, 4-poradas. Ovário adnato até a metade ao hipanto, glabro, 3-locular.

Material selecionado: BRASIL. Minas GeraIs: Poços de Caldas, Campo do Saco, 30-XI-1982, H.F. Leitão Filho et al. 1714 (UEC).

Miconia theaezans apresenta ampla distribuição geográfica, ocorrendo desde a América Central até Santa Catarina. Ocupa campos e matas caducifólias, locais arenosos, úmidos e brejos (Martins et al. 1996, Goldenberg 2004). No município de Poços de Caldas esta espécie ocorre em campo sujo, em áreas brejosas.

\subsection{Miconia tristis Spring subsp. tristis, Flora 20} (2): 76.1837.

Arbustos a árvores 2-8 m alt. Caule, ramos, face adaxial das folhas e hipanto glabrescentes a glabros. Folhas com pecíolo 3-10 mm compr.; lâmina 7,5-12×
2,5-4,5 cm, elíptica a oblongo-lanceolada, base aguda, ápice longo-acuminado, margem inteira a ondulada, face abaxial esparsamente estrelado-furfurácea; 1-2 par de nervuras acródromas suprabasais; domácias ausentes. Panículas terminais e laterais. Flores 5-meras. Hipanto $2 \times 1,5 \mathrm{~mm}$, campanulado . Cálice caduco, lacínias internas $1 \times 0,5 \mathrm{~mm}$, arredondadas, as externas $0,8 \times 0,4 \mathrm{~mm}$, triangulares. Pétalas $2 \times$ $1,3 \mathrm{~mm}$, rosadas, obovais. Estames com filetes $2 \mathrm{~mm}$ compr.; conectivo espessado e calcarado no dorso; anteras 1,5-2 ×0,3 mm, lineares, levemente atenuadas na base, ápice truncado, uniporadas. Ovário adnato até o segundo terço superior ao hipanto, glabro, 3-locular.

Material selecionado: BRASIL. Minas Gerais: Poços de Caldas, Mata da Colina, 19-05-1981, F.R. Martins et al. 237 (UEC).

Miconia tristis subsp. tristis ocorre nos Estados de Bahia, Minas Gerais, Rio de Janeiro e São Paulo, em matas e locais sombreados (Martins et al. 1996, Goldenberg 2004). No município de Poços de Caldas foi coletada em matas.

\section{Agradecimentos}

Aos curadores dos Herbários UEC, HB, IAC, $\mathrm{R}, \mathrm{RB}, \mathrm{S}, \mathrm{SP}$, pelo empréstimo dos materiais, ao Dr. Fabián Michelangeli, Dr. Frank Almeda, Dr. Renato Goldenberg, e à Dra. Maria do Carmo E. Amaral pelas fotos disponibilizadas. Agradecemos também a Iria Benedita Baldassari pelo estudo realizado em Poços de Caldas, que constituiu a base para o desenvolvimento deste trabalho.

\section{Literatura citada}

Almeda, F. \& Robinson, O.R. 1999. Merger of the monotipic genus Farringtonia and Siphanthera (Melastomataceae). Novon 9: 131.

Baumgratz, J.F.A. 1980. Miconias do município do Rio de Janeiro. Seção Miconia DC. (Melastomataceae). Rodriguésia 32: 73-95.

Baumgratz, J.F.A. 1984. Miconias do Estado do Rio de Janeiro. Seção Chaenanthera Naud. (Melastomataceae). Rodriguésia 36: 45-58.

Candido, J.F. \& Griffith, J.J. 1978. Recomendações para a recuperação de superfícies mineradas de bauxita. Viçosa. Escola Superior de Florestas.

Christofolletti, A. 1972. Características Fisiográficas do Planalto de Poços de Caldas (MG, Brasil). Geomorfologia. São Paulo, 32: 1-26. 
Cogniaux,A. 1883-1885. Melastomataceae Tribus I Microlicieae et Tribus II Tibouchineae. In: C.F.P. Martius; A.G. Eichler \& I. Urban (eds.). Flora Brasiliensis. Typographia Regia, Monachii. v. 14, pt. 3, pp. 1-510, t. 1-108.

Cogniaux, A. 1886-1888. Melastomataceae Tribus III Rhexieae, Tribus IV Merianieae, Tribus V Bertolonieae, Tribus VI Miconieae, Tribus VII Blakeae, Tribus VIII Memecyleae. In: C.F.P. Martius; A.G. Eichler \& I. Urban (eds.). Flora Brasiliensis. Typographia Regia, Monachii. v. 14, pt. 4, pp. 1-655, t. 1-130.

Fritsch, P.W., Almeda, F., Renner, S.S., Martins, A.B., Cruz, B. 2004. Phylogeny and circumscription of the nearendemic Brazilian tribe Microlicieae (Melastomataceae). American Journal of Botany 91: 1105-1114.

Goldenberg, R. 2004. O gênero Miconia (Melastomataceae) no Estado do Paraná. Acta botanica brasilica. Brasil. 18: 927-947.

Guimarães, P.J.F. 1997. Estudos taxonômicos de Tibouchina sect. Pleroma (D. Don) Cogn. (Melastomataceae). Tese de Doutorado. Universidade Estadual de Campinas, Campinas.

Guimarães, P.J.F. \& Martins, A.B. 1997. Tibouchina sect. Pleroma (D. Don) Cogn. (Melastomataceae) no Estado de São Paulo. Revista Brasileira de Botânica 20: 11-33.

Martins, A.B. 1984. Revisão Taxonômica do gênero Cambessedesia DC. (Melastomataceae). Dissertação de Mestrado. Universidade Estadual de Campinas, Campinas.

Martins, A.B. 1989. Revisão taxonômica do gênero Marcetia DC. (Melastomataceae). Tese de Doutorado. Universidade Estadual de Campinas, Campinas.

Martins, A.B. 1993. New species in Brazilian Melastomataceae. Kew Bulletin 48: 385-389.

Martins, A.B., Semir, J., Goldenberg, R. \& Martins, E. 1996. O gênero Miconia Ruiz et Pav. no Estado de São Paulo. Acta Botanica Brasilica 10: 267-316.

Martins, E. 1997. Revisão taxonômica do gênero Trembleya DC. (Melastomataceae). Tese de Doutorado. Universidade Estadual de Campinas, Campinas.

Michelangeli, F.A., Penneys, D.S., Giza, J., Soltis, D., Hills, M.H. \& Skean Jr., J.D. 2004. A preliminary phylogeny of the tribe Miconieae (Melastomataceae) based on nrITS sequence data and its implications on inflorescence position. Taxon 53: 279-290.

Morley, R.J. \& Dick, C.W. 2003. Missing fossils, molecular clocks, and the origin of the Melastomataceae. American Journal of Botany 90: 1638-1644.

Oliveira, C.M.S. 2001. Tibouchina sect. Diotanthera, Diplostegia, Pseudoptrolepis, Purpurella e Simplicicaules (Melastomataceae) no Estado de São Paulo. Dissertação de Mestrado. Universidade Estadual de Campinas, Campinas.
Pereira, S.C. 1986. Contribuição ao conhecimento das Gramíneas do município de Poços de Caldas - MG. Tese de Doutorado. Universidade Federal de Lavras, Lavras.

Prefeitura Municipal de Poços de Caldas, INDI, CDI. 1974. Poços de Caldas - informações básicas para investidores. Poços de Caldas.

Renner, S.S. 1990. Revision of Rhynchanthera (Melastomataceae). Nordic Journal of Botany 9: 601-630.

Renner, S.S. 1993. Phylogeny and classification of the Melastomataceae and Memecylaceae. Nordic Journal of Botany 13: 519-540.

Renner, S.S. 1994. A revision of Pterolepis (Melastomataceae: Melastomeae). Nordic Journal of Botany 14: 73-104.

Rodrigues, T.S. 2001. A flora fanerogâmica do município de Poços de Caldas, Estado de Minas Gerais: família Asteraceae. Dissertação de Mestrado. Universidade Estadual de Campinas, Campinas.

Rodrigues, K.F. 2005. A tribo Microlicieae (Melastomataceae) na Serra do Cabral, Minas Gerais, Brasil. Tese de Mestrado. Universidade Estadual de Campinas, Campinas.

Romero, R. 2003. Revisão taxonômica de Microlicia sect. Chaestomoides (Melastomataceae). Revista Brasileira de Botânica 26: 429-435.

Romero, R. \& Martins, A.B. 2002. Melastomataceae do Parque Nacional da Serra da Canastra, Minas Gerais, Brasil. Revista Brasileira de Botânica 25: 19-24.

Seco, R.C. 2006. Estudos taxonômicos no gênero Comolia DC. (Melastomeae-Melastomataceae). Dissertação de Mestrado. Universidade Estadual de Campinas, Campinas.

Souza, M.L.D.R. 1998. Revisão taxonômica do gênero Ossaea DC. (Melastomataceae) no Brasil. Tese de Doutorado. Universidade de São Paulo, São Paulo.

Souza, M.L.D.R. \& Baumgratz, J.F.A. 2005. Leandra lapae D’el Rei Souza\& Baumgratz (Seção Leandraria; Miconieae: Melastomataceae), nova espécie do Brasil. Revista Brasileira de Botânica 28: 419-421.

Vasconcellos, M.B. \& Kinoshita, L.S. 1993. As Apocynaceae da região de Poços de Caldas, Minas Gerais, Brasil. Acta botanica brasilica 7: 107-127.

Wurdack, J.J. 1962. Melastomataceae of Santa Catarina. Sellowia 14: 109-217.

Wurdack, J.J. 1983. Certamen Melastomataceis. Pytologia 49: $148-158$. 